\title{
Annotated review of Cryptocephalinae (Clytrini), Synetinae and part of Galerucinae (Coleoptera, Chrysomelidae) described by Carl Peter Thunberg
}

\author{
Jan BEZDĚK \\ Department of Zoology, Fisheries, Hydrobiology and Apiculture, Mendel University in Brno, \\ Zemědělská 1, CZ-613 00 Brno, Czech Republic. \\ Email: bezdek@mendelu.cz \\ urn:lsid:zoobank.org:author:668F3A35-3E6E-40F3-9F06-356EEB50E45F
}

\begin{abstract}
The taxa of Cryptocephalinae (Clytrini), Synetinae and part of Galerucinae introduced by Carl Peter Thunberg are reviewed based on the examination of primary type specimens deposited in the Museum of Evolution, Uppsala University. The following taxonomic changes are proposed: Coptocephala unifasciata unifasciata $($ Scopoli, 1763) = Cryptocephalus melanocephalus Thunberg, 1787 syn. nov.; Melitonoma decemnotata (Thunberg, 1787) comb. nov. (from Cryptocephalus Geoffroy, 1762); Miopristis flexuosa (Thunberg, 1821) = Miopristis namaquensis Medvedev, 1993 syn. nov.; Protoclytra (Lacordairella) taeniata (Thunberg, 1821) comb. nov. (from Camptolenes Chevrolat, 1836) = Camptolenes fastuosa (Lacordaire, 1848) syn. nov.; Smeia undata (Thunberg, 1821) comb. nov. (from Miopristis Lacordaire, 1848) = Smeia virginea $($ Lacordaire, 1848) syn. nov. = Melitonoma pictipennis Jacoby, 1898 syn. nov.; Teinocera catenata (Thunberg, 1821) comb. nov. (from Miopristis) = Teinocera subclathrata (Lacordaire, 1848) syn. nov.; Exosoma lusitanica (Linnaeus, $1767)=$ Crioceris haemorrhoa Thunberg, 1827 syn. nov.; Megalognatha festiva (Fabricius, 1781) = Crioceris virens Thunberg, 1827 syn. nov.; Monolepta bioculata (Fabricius, 1781) $=$ Cryptocephalus bioculatus Thunberg, 1827 syn. nov.; Monolepta melanogaster $($ Wiedemann, 1823) $=$ Cryptocephalus capensis Thunberg, 1827 syn. nov.; Palaeophylia tricolor (Fabricius, 1781) = Crioceris tetrapuncta Thunberg, 1787 syn. nov. $=$ Crioceris dimidiata Thunberg, 1827 syn. nov. Lectotypes are designated for Cryptocephalus bioculatus Thunberg, 1827 and Crioceris dimidiata Thunberg, 1827. Melitonoma decemnotata comb. nov. is redescribed. Labidostomis insidiosa Péringuey, 1888 is resurrected from synonymy with Teinocera catenata comb. nov. and provisionally placed as a valid species in the genus Miopristis Lacordaire, 1848. Crioceris betulina Thunberg, 1787 is proposed as nomen oblitum for Syneta betulae (Fabricius, 1792) (nomen protectum). Colour photographs of the type specimens of all taxa are provided.
\end{abstract}

Keywords. New synonymy, new combination, lectotype designation, taxonomy, Carl Peter Thunberg.

Bezděk J. 2019. Annotated review of Cryptocephalinae (Clytrini), Synetinae and part of Galerucinae (Coleoptera, Chrysomelidae) described by Carl Peter Thunberg. European Journal of Taxonomy 499: 1-42.

https://doi.org/10.5852/ejt.2019.499 


\section{Introduction}

The famous Swedish botanist and naturalist Carl Peter Thunberg (1743-1828), one of the pupils of Linnaeus, travelled widely from 1771-1779, visiting other European countries, South Africa, Sri Lanka, Java and Japan. Although Thunberg is usually described as a botanist, he also published important contributions on mammals, birds and insects (Muller \& Roomaaker 1992). He is the author of nearly 90 entomological publications and his insect collection of about 25000 specimens was donated to the University of Uppsala where it is still maintained in very good condition. For the catalogue of his collection see Wallin \& Wallin (2001). Thunberg's collection also includes the type specimens of Clytrini species described by Forsberg (1821) which were already revised by Bezděk (2016).

Altogether Thunberg described about 100 species of Chrysomelidae. Due to many taxonomic difficulties, it is not possible to review all of these at once. Some groups require the cooperation of additional specialists and also the study of many primary type specimens of other authors. In the present paper I include one representative of Synetinae, all of Thunberg's Clytrini species and part of his Galerucinae.

In Clytrini, Thunberg proposed 15 new taxa altogether. Except for three species described at the beginning of his career (Thunberg 1787), most of the taxa were proposed in his Coleoptera Capensia (Thunberg 1821). Due to his poor state of health, Thunberg published only short descriptions in Coleoptera Capensia as explained in the introduction to Forsberg (1821) who was asked to provide extended redescriptions (for details see Bezděk 2016).

In two cases (Clythra unipunctata Thunberg, 1821 and C. bicincta Thunberg, 1821), it is not quite clear whether Thunberg (1821) wanted to propose new replacement names for already described taxa, because in the description there is a clear reference to an older publication and species. However, also in these cases the 'new name' is accompanied by a description and there is no evidence of intentional replacement. I can only speculate why Thunberg wanted to give new names for non-homonymous older names. The question is how to apply such cases to the current Code (ICZN 1999). In my opinion, the crucial facts are that 1) the intention to replace the names is missing, and 2) Thunberg treated these names as valid, not as synonyms. Because the names are accompanied by descriptions, I prefer to work with them as if validly described.

The genus assignments proposed for some of Thunberg's Clytrini species are provisional. This is particularly the case with species classified in Miopristis Lacordaire, 1848, Protoclytra Weise, 1905 and Smeia Lacordaire, 1848. The definitions of these genera are superficial, with many species wrongly classified, and comprehensive studies are absent. I cannot exclude future transfers to other genera.

In Synetinae, Thunberg (1787) described only one nominal taxon, forgotten for many years, which is proposed here as nomen oblitum.

Thunberg $(1787,1814,1827)$ described 13 Galerucinae species altogether (excluding Alticini). Ten species were proposed in Crioceris Geoffroy, 1762, two in Cryptocephalus Geoffroy, 1762, one in Taumacera Thunberg, 1814. At present I am not able to resolve the species identity of six Galerucinae species as the comparison with the type material of other species, additional examination and/or dissection of the aedeagus are necessary. Alticini itself will be also published separately in the future.

\section{Material and methods}

\section{Images}

Photographs of specimens deposited in UUZM, BMNH and NHMB were taken with a Canon EOS 550D digital camera with a Canon MP-E $65 \mathrm{~mm}$ lens. Images of the same specimen at different focal planes were combined using Helicon Focus 5.3 software. 


\section{Material citations}

Exact label data are cited for all type specimens: a double slash (//) divides the data on different labels, and a single slash (/) divides the data in different lines. Type localities are cited in the original spelling. Other comments and remarks are placed in square brackets: $[\mathrm{p}]=$ preceding data are printed, $[\mathrm{h}]=$ preceding data are handwritten, $[\mathrm{w}]=$ white label, $[\mathrm{r}]=$ red label.

\section{Type specimens}

The type specimens deposited in Thunberg's collection were located and provided with red type labels by Wallin \& Wallin (2001). To the best of my knowledge, Thunberg's Chrysomelidae type specimens are deposited exclusively in UUZM. Therefore I treat all single type specimens in Thunberg's collection as holotypes in agreement with my previous study dealing with the taxa described by Carl Peter Forsberg from Thunberg's collection (Bezděk 2016). The lectotypes are designated only in cases when the type series consists of more than one species.

The type specimens from Thunberg's collection were not dissected (except the holotype of Crioceris haemorrhoa) particularly to avoid damage to historical specimens during the risky remounting.

\section{Repositories}

BMNH $=$ The Natural History Museum, London, UK (Michael Geiser, Maxwell V. L. Barclay)

LMRM $=$ Lev N. Medvedev collection, Moscow, Russia

NHMB = Naturhistorisches Museum, Basel, Switzerland (Matthias Borer)

NHRS = Naturhistoriska Riksmuseet Stockholm, Sweden (Johannes Bergsten)

SAMC $=$ IZIKO South African Museum, Cape Town, South Africa (Aisha Mayekiso)

UUZM = Museum of Evolution, Uppsala University, Sweden (Hans Mejlon)

ZMHB = Museum für Naturkunde der Humboldt-Universität, Berlin, Germany (Johannes Frisch, Joachim Willers)

ZMK = Universität Kiel, Zoologisches Museum, Kiel, Germany (Michael Kuhlmann)

\section{Results}

Class Hexapoda Latreille, 1825

Order Coleoptera Linnaeus, 1758

Suborder Polyphaga Emery, 1886

Superfamily Chrysomeloidea Latreille, 1802

Family Chrysomelidae Latreille, 1802

Subfamily Cryptocephalinae Gyllenhal, 1813

Tribe Clytrini Kirby, 1837

Genus Antipus DeGeer, 1778

Antipus rufus rufus DeGeer, 1778

Fig. 1

Antipus rufus DeGeer, 1778: 659 (original description).

Cryptocephalus maxillosus Fabricius, 1781: 139 (original description).

Clytra capensis Olivier, 1808: 853 (original description) (not examined).

Clythra unipunctata Thunberg, 1821: 183 (original description) (not examined).

Clythra octonotata Thunberg, 1821: 184 (original description).

Micropyga transvalense Jacoby, 1903: 93 (original description) (not examined). 

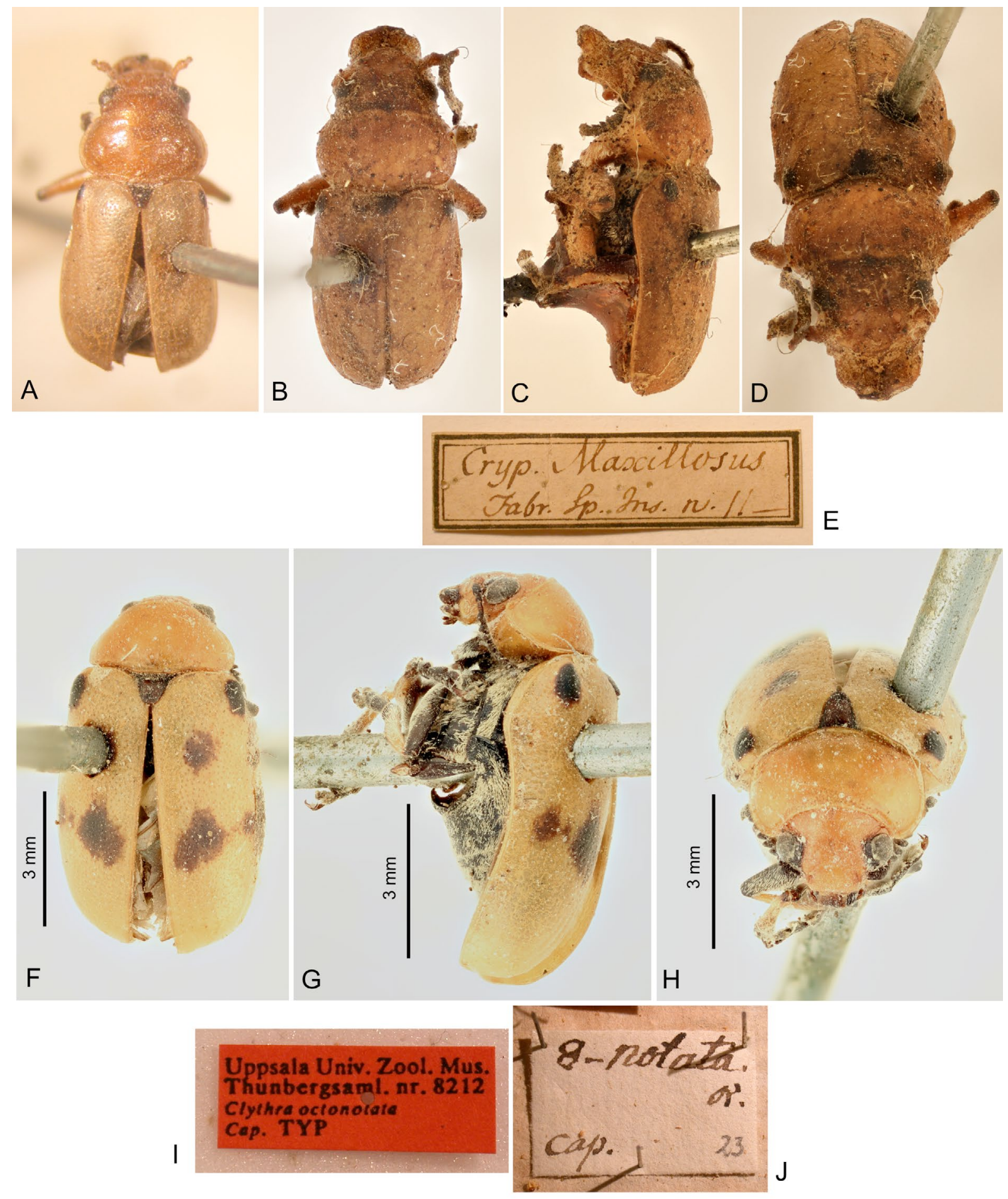

Fig. 1. Antipus rufus DeGeer, 1778. A. Syntype, đ̊, not measured, NHRS. B-E. Syntype of Cryptocephalus maxillosus Fabricius, 1781, $\widehat{\jmath}$, not measured, BMNH. B. Dorsal view. C. Lateral view. D. Frontal view. E. Label. F-J. Syntype of Clythra octonotata Thunberg, 1821, + , $7.5 \mathrm{~mm}$, UUZM. F. Dorsal view. G. Lateral view. H. Frontal view. I. Label. J. Box label. 


\section{Type localities}

Antipus rufus: "Cap". Cryptocephalus maxillosus: "Cap. bon. sp.". Clytra capensis: "cap de BonneEspérance". Clythra unipunctata: "Cap" [= from the publication title]. Clythra octonotata: "Cap" [= from the publication title]. Micropyga transvalense: "Transvaal".

\section{Material examined}

\section{Syntypes}

SOUTH AFRICA • 1 §’; "Sp. [w, h] // Antipus rufus. VII p 659 [box label common for both specimens, w, h]"; NHRS • 1 $\widehat{\jmath}$, without any labels; NHRS.

\section{Additional material}

SOUTH AFRICA 11 , syntype of Cryptocephalus maxillosus; “Cryp. Maxillosus / Fabr. Sp. Ins. n. 11 [w, h]"; BMNH - Banks coll. • 1 +, syntype of Clythra octonotata; "Uppsala Univ. Zool. Mus. I Thunbergsaml. nr. 8212 / Clythra octonotata / Cap. TYP [r, p] // 8-notata. / a / Cap. 23 [box label, w, h]"; UUZM • 1 क (almost destroyed), syntype of Clythra octonotata; "Uppsala Univ. Zool. Mus. / Thunbergsaml. nr. 8213 / Clythra octonontata / Cap. TYP [r, p] // 8-notata. / $\beta$ / Cap. 24 [box label, w, h]"; UUZM • 1 क , syntype of Clythra octonotata; "Uppsala Univ. Zool. Mus. / Thunbergsaml. nr. 15384 / Clythra octonotata / TYP [r, p] // 8-notata. / 110x [box label, w, h]”; UUZM.

\section{Distribution}

Republic of South Africa (RSA).

\section{Comments}

Thunberg (1821) accompanied the name Clythra unipunctata with a very short description and a reference to Cryptocephalus maxillosus Fabricius, 1781. I can only speculate whether Thunberg wanted to replace the older name or not. However, because there is no explicit intention of replacement, I treat Clythra unipunctata as a validly described species conspecific with Cryptocephalus maxillosus. In UUZM, no type specimens of Clythra unipunctata were traced.

In the same paper, Thunberg (1821) described Clythra octonotata. In UUZM three female syntypes are deposited (one almost destroyed). The syntypes belong to a colour aberration with black spots on elytra often occurring in females of Antipus rufus rufus. Lacordaire (1848) correctly listed Clythra octonotata under his variety B of Antipus rufus rufus. Here I confirm Clythra octonotata as a synonym of Antipus rufus rufus.

The genus Antipus DeGeer, 1778 includes three species: A. nasicornis Medvedev, 2008 (Congo), A. signatifera (Lacordaire, 1848) (RSA) and the widely distributed Antipus rufus DeGeer, 1778 forming three subspecies (Antipus r. rufus; Antipus r. cornuta Medvedev, 1993; Antipus r. haefligeri (Weise, 1907)). The genus requires a modern taxonomic revision.

Genus Atelechira Lacordaire, 1848

Atelechira elegans (Thunberg, 1821)

Fig. 2

Clythra elegans Thunberg, 1821: 184 (original description).

\section{Type locality}

"Cap" [= from the publication title]: Western Cape Province, Republic of South Africa. 


\section{Material examined}

\section{Holotype}

SOUTH AFRICA • đ̃, "Uppsala Univ. Zool. Mus. / Thunbergsaml. nr. 8211 / Clythra elegans / Cap. TYP [r, p] // elegans. / Cap. 22 [box label, w, h]”; UUZM.

\section{Additional material}

SOUTH AFRICA - Eastern Cape • 2 q $q$; Dunbrody; 23 Feb. 1907; BMNH • 3 ôd, 2 q $q$; Somerset

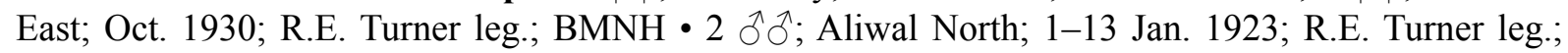

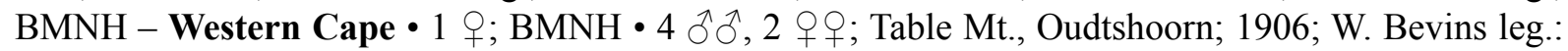
BMNH • 1 ภ, 1 क; Matjesfontein; 19-31 Dec. 1928; R.E. Turner leg.; BMNH - KwaZulu-Natal • 1 \%;

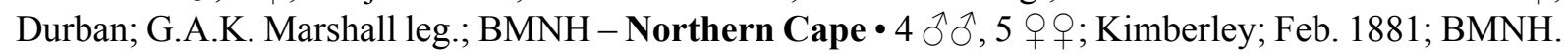

ZIMBABWE • 1 §̊; S. Rhodesia, Salisbury; G.A.K. Marshall leg.; BMNH.

NAMIBIA • 1 ; ; 27 miles NNE Grunau, Noachabeb; 10-12 Jan. 1972; BMNH.

\section{Distribution}

RSA. Newly recorded for Zimbabwe and Namibia.
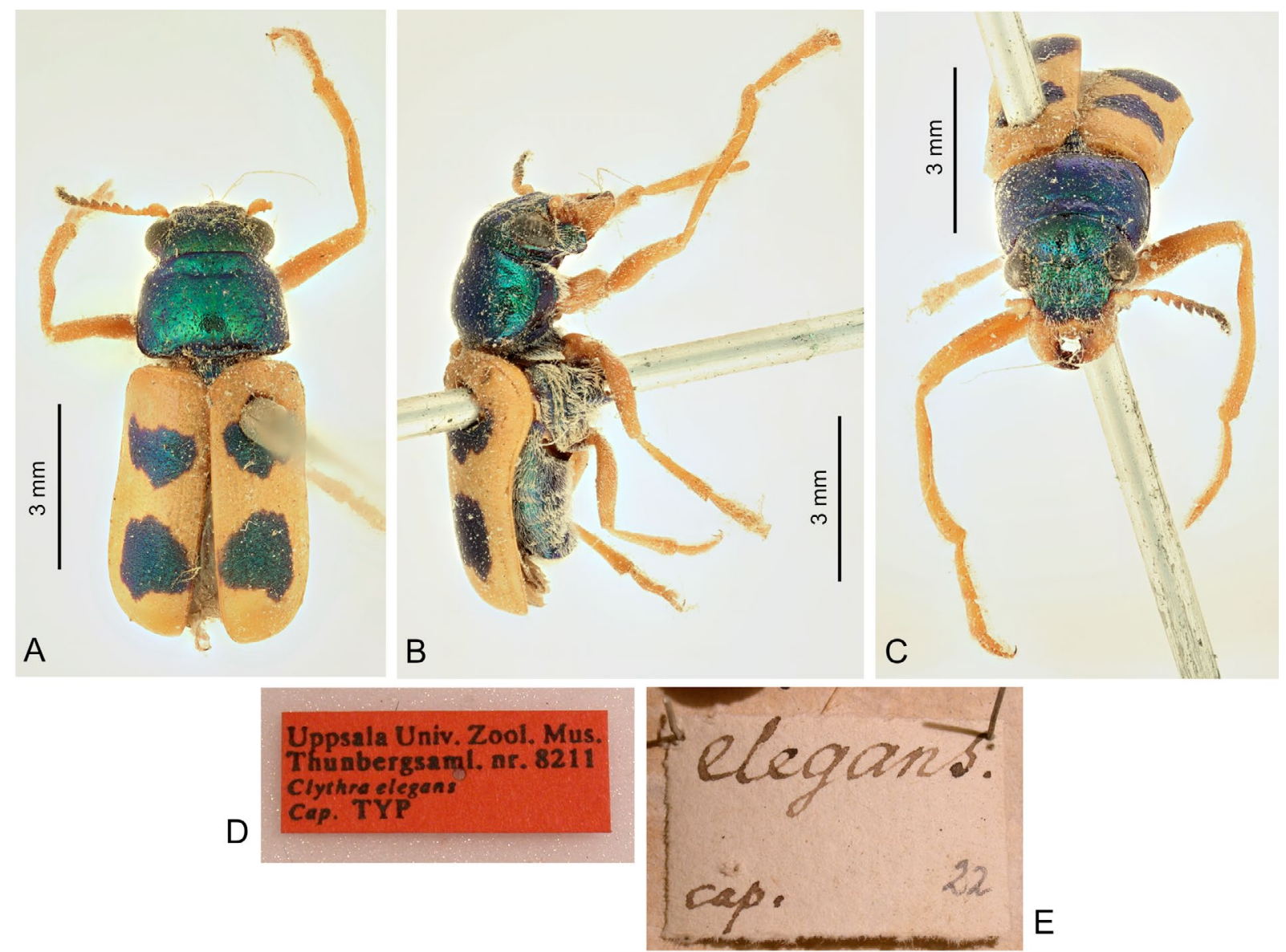

Fig. 2. Atelechira elegans (Thunberg, 1821), holotype, ふ̊, 7.5 mm, UUZM. A. Dorsal view. B. Lateral view. C. Frontal view. D. Label. E. Box label. 


\section{Comments}

Clythra elegans was synonymized with another South African species Atelechira aulica (Fabricius, 1781) by Lacordaire (1848). This synonymy was accepted by all subsequent authors. However, it was recently discovered that the holotype of Crioceris aulica deposited in Banks' collection in BMNH is a representative of Hadrocnemus Kraatz, 1895 (Malachiidae). Subsequently, Atelechira elegans was restored as correct name for Clytrini species (for details see Geiser \& Bezděk in press).

Lacordaire (1848) proposed the subgeneric name Atelechira Lacordaire, 1848 with two included species, Clythra (Atelechira) aulica and C. (A.) baculus Lacordaire, 1848. Medvedev (1993a) designated Atelechira aulica as the type species of Atelechira. Because this designation was based on a misapplication of a previously established nominal species, the type of Atelechira is Atelechira elegans (Thunberg, 1821) (see ICZN, Art. 69.2.4).

Currently, the genus Atelechira comprises ten species. All of them except A. schultzei Weise, 1905 from Nigeria were keyed by Medvedev (1993a). The generic assignment of Atelechira foersbergi (Lacordaire, 1848) needs confirmation as it was also classified in Merilia Lacordaire, 1848 by Medvedev \& Erber (2003). Atelechira elegans can be distinguished from its congeners by the combination of the following characters: pronotum punctate, elytra dull, legs completely yellow, mandibles yellow (Lacordaire 1848; Medvedev 1993a).

Genus Clytra Laicharting, 1781

\section{Clytra bifasciata bifasciata (DeGeer, 1778)}

Chrysomela bifasciata DeGeer, 1778: 663 (original description).

Clythra rugosa Fabricius, 1798: 111 (original description).

Clythra bicincta Thunberg, 1821: 185 (original description) (not examined).

Clythra mutabilis Klug, 1829: 16 (original description) (not examined).

Clythra bicincta - Forsberg 1821: 268, 287 (redescription).

\section{Type localities}

Chrysomela bifasciata: not stated; Clythra rugosa: "Cap. Bon. Spei"; Clythra bicincta: "Cap" [= from the publication title]; Clythra mutabilis: "Kap".

\section{Material examined}

\section{Syntypes}

SOUTH AFRICA • 1 क; "Sp. [w, h] // C. bifasciata VII. 664 [box label, w, h]"; NHRS • 1 क; "[small blank orange label] // C. bifasciata VII. 664 [box label, w, h]"; NHRS.

\section{Additional material}

SOUTH AFRICA • 1 क, syntype of Clythra rugosa; "C: rugosa / e Cap: b: sp: Paykull [w, h]"; ZMK $\cdot 1$ ô, syntype of Clythra rugosa; without any label; ZMK.

\section{Distribution}

RSA.

\section{Comments}

Clytra bifasciata was treated as synonym of Clythra rugosa by Schoenherr (1808) but with reversed priority. Lacordaire (1848) correctly gave the priority to Clytra bifasciata and in synonymy he listed 
both Clythra rugosa and Clythra bicincta. Gemminger \& Harold (1874) also added Clythra mutabilis to the synonyms of Clytra bifasciata. The same arrangement was accepted also in subsequent catalogues by Jacoby \& Clavareau (1906) and Clavareau (1913). I examined the type specimens of Chrysomela bifasciata and photographs of the syntypes of Clythra rugosa, and undoubtedly they are conspecific.

Thunberg (1821) introduced the name Clythra bicincta with Clythra rugosa Fabricius, 1798 placed in synonymy. As discussed in the introduction, it is not quite clear whether or not Thunberg (1821) wanted to propose a new replacement name for Clythra rugosa. As explained above I treat Clythra bicincta as a validly described species. The type specimen(s) were not traced in UUZM. Because its original description by Thunberg (1821) and also redescription by Forsberg (1821) agree with Clytra bifasciata bifasciata, I confirm Clythra bicincta as its synonym.

Clytra bifasciata ssp. pallipes Medvedev, 1993, also described from the Western Cape Province, differs from nominal subspecies only in the pale tibiae and tarsi (Medvedev 1993a) and its validity needs confirmation.

Genus Coptocephala Chevrolat, 1836

Coptocephala unifasciata unifasciata (Scopoli, 1763)

Fig. 3A-E

Buprestis unifasciata Scopoli, 1763: 66 (original description) (not examined).

Cryptocephalus melanocephalus Thunberg, 1787: 46 (original description). Syn. nov.

For a full list of synonyms, see Regalin \& Medvedev (2010).

\section{Type localities}

Buprestis unifasciata: Carniolia [= Slovenia, based on title]; Cryptocephalus melanocephalus: not stated.

\section{Material examined}

COUNTRY UNKNOWN • $q$, holotype of Cryptocephalus melanocephalus; "Uppsala Univ. Zool. Mus. / Thunbergsaml. nr. 8198 / Clythra bimaculata / melanoceph. TYP [r, p] // 2-maculata. / melanoceph. 13 [box label, w, h]"; UUZM.

\section{Distribution}

Europe (except northern part), Turkey, Kazakhstan, Mongolia (Regalin \& Medvedev 2010).

\section{Comments}

The holotype of Cryptocephalus melanocephalus is a female of Coptocephala. Although the identification of Coptocephala females is usually very complicated, the colouration of the head (black with orange labrum), elytra (two broad transverse metallic bands on each elytron) and legs (orange with dark basal halves of meso- and metafemora) is typical of the common European C. unifasciata unifasciata. As I see no differences between long series of $C$. unifasciata unifasciata and the holotype of Cryptocephalus melanocephalus, I propose a new synonymy: C. unifasciata unifasciata (Scopoli, $1763)=$ Cryptocephalus melanocephalus Thunberg, 1787 syn. nov. 
Gyriodera cruciata (Thunberg, 1821)

Fig. 3F-J

Clythra cruciata Thunberg, 1821: 184 (original description).

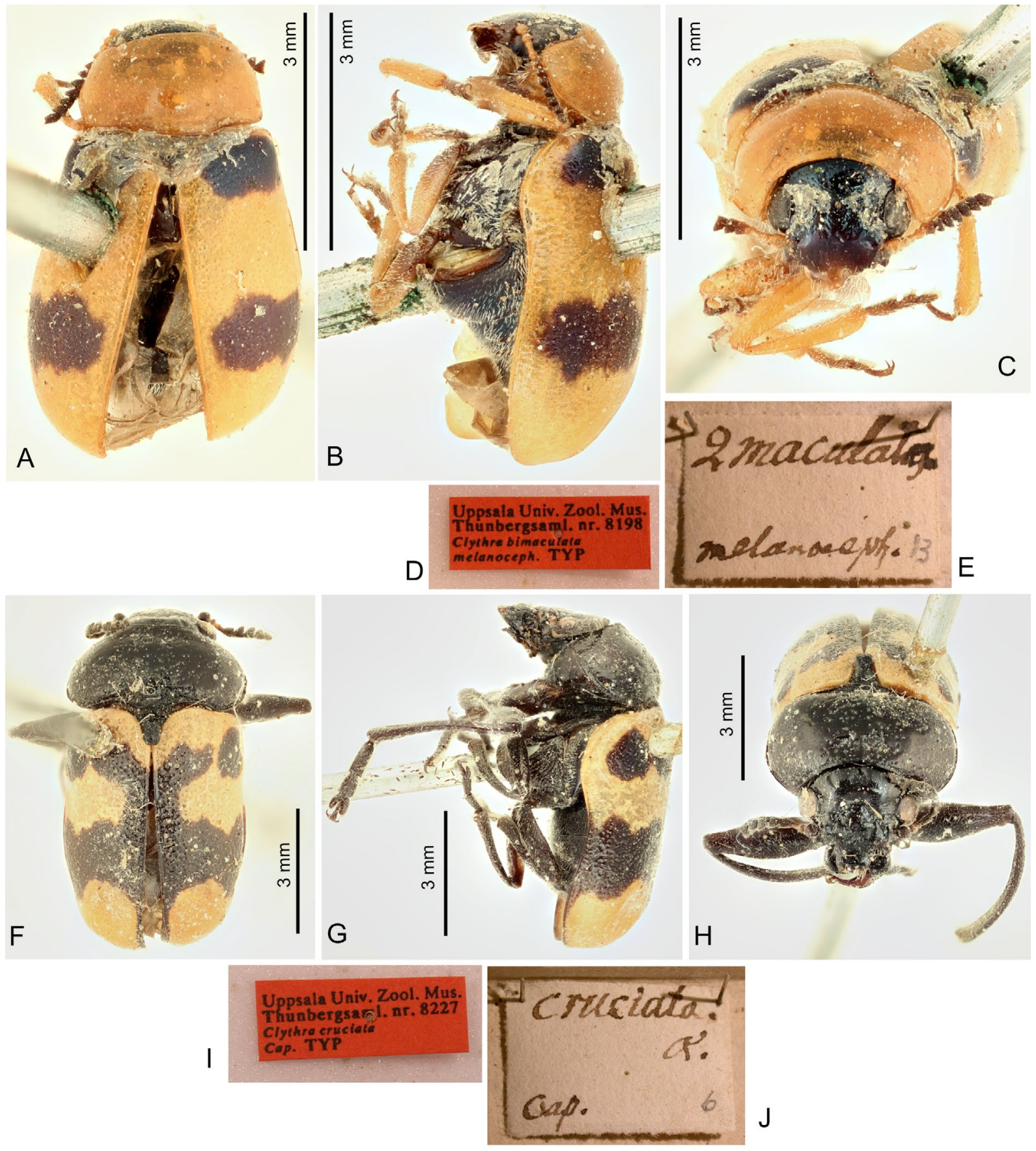

Fig. 3. A-E. Coptocephala unifasciata unifasciata (Scopoli, 1763), syntype of Cryptocephalus melanocephalus Thunberg, 1787,, , $5.5 \mathrm{~mm}$, UUZM. A. Dorsal view. B. Lateral view. C. Frontal view. D. Label. E. Box label. F-J. Syntype of Gyriodera cruciata (Thunberg, 1821), ठ̂, 8.0 mm, UUZM. F. Dorsal view. G. Lateral view. H. Frontal view. I. Label. J. Box label. 
Clythra cruciata - Forsberg 1821: 286 (redescription).

Clythra (Gyriodera) cruciata - Lacordaire 1848: 122.

Tituboea cruciata - Gemminger \& Harold 1874: 3283 (catalogue).

Tituboea (Gyriodera) cruciata - Jacoby \& Clavareau 1906: 25, pl. 2, fig. 12 (catalogue).

Antipa (Gyriodera) cruciata - Clavareau 1913: 40 (catalogue).

\section{Type locality}

"Cap" [= from the publication title].

\section{Type material examined}

SOUTH AFRICA • 1 $\hat{\delta}$, syntype of Clythra cruciata; "Uppsala Univ. Zool. Mus. / Thunbergsaml. nr. 8227 / Clythra cruciata / Cap. TYP [r, p] // cruciata. / $\alpha$. / Cap. 6 [box label, w, h]"; UUZM • 1 o,, syntype of Clythra cruciata; "Uppsala Univ. Zool. Mus. / Thunbergsaml. nr. 8228 / Clythra cruciata / Cap. TYP [r, p] // cruciata. / $\beta$. / Cap. 7 [box label, w, h]"; UUZM.

\section{Distribution}

RSA.

\section{Comments}

The collection of UUZM houses two male syntypes of Clythra cruciata, one in good condition, the second with head and pronotum broken and artificially stuck back in the wrong position. Both examined syntypes agree well with the species definition of Gyriodera cruciata used in subsequent publications (Lacordaire 1848; Jacoby \& Clavareau 1906; Medvedev 1989b).

Currently, the genus Gyriodera Lacordaire, 1848 includes ten species, but the position of G. capensis (Lacordaire, 1848) is uncertain and it should probably be moved to the genus Smaragdina Chevrolat, 1836. The genus was keyed by Medvedev (1989b). Clythra cruciata is the type species of Gyriodera designated by Lacordaire (1848).

Genus Melitonoma Chevrolat, 1836

Melitonoma decemnotata (Thunberg, 1787) comb. nov.

Figs 4-5

Cryptocephalus 10-notatus Thunberg, 1787: 47 (original description).

\section{Type locality}

Not stated.

\section{Material examined}

\section{Holotype}

SOUTH AFRICA • + ; type locality not stated (see Comments); "[small blank label] // Uppsala Univ. Zool. Mus. / Thunbergsaml. nr. 9582 / Cryptocephalus decemnotatus / Mus. Thunb. TYP [r, p] // 10 - notata. / 19 / Mus. Thunb. [box label, w, h]"; UUZM.

\section{Additional material}

SOUTH AFRICA - Western Cape province • 1 § , 1 क; Worcester; Jan. 1929; B.E. Turner leg.; BMNH - 1 q; "P.B. Spei" [= Cape of Good Hope]; BMNH. 


\section{Redescription}

Body LENGth. đ̊: $6.1 \mathrm{~mm}$, + q : 5.1-5.8 mm (holotype $+: 5.8 \mathrm{~mm}$ ).
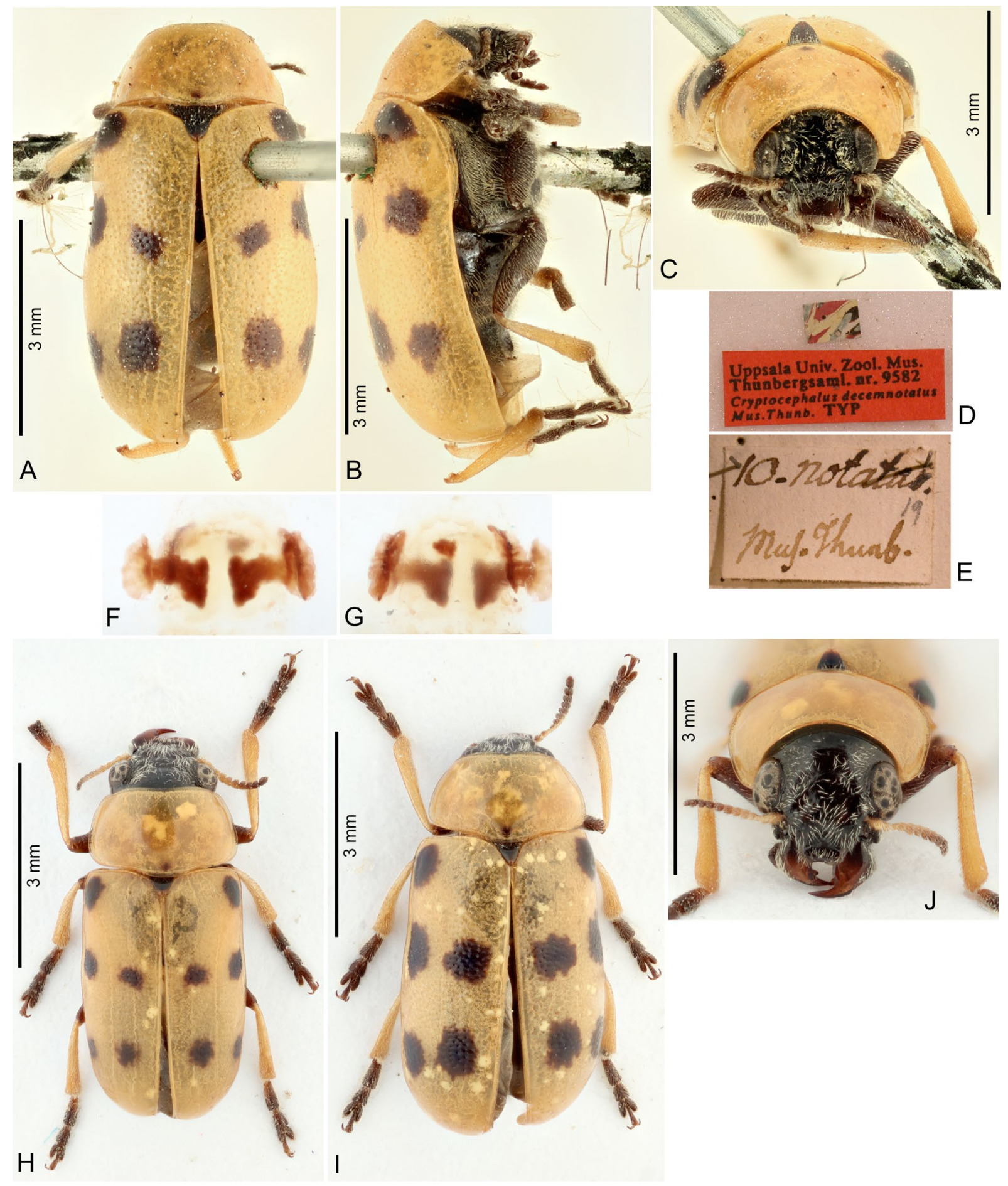

Fig. 4. Melitonoma decemnotata (Thunberg, 1787) comb. nov. A-E. Syntype,,$+ 5.8 \mathrm{~mm}$, UUZM. A. Dorsal view. B. Lateral view. C. Frontal view. D. Labels. E. Box label. F-G. Kotpresse. F. Ventral

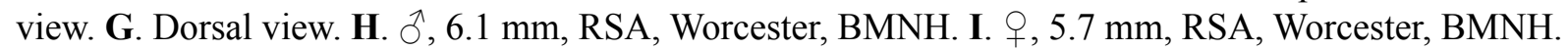
J. Male head, frontal view. 
MaLE (Fig. 4H). Head black, apical halves of mandibles reddish, antennae yellow, antennomeres VIIVIII brownish basally, apices gradually darkened, IX-XI black. Pronotum orange with small blurry dark spot near middle of posterior margin. Scutellum black with orange tip. Elytra orange, each elytron with 5 small black round spots $(1,2,2)$. Underside black. Legs black with pale femora and bases of first two protarsomeres.

HEAD (Fig. 4J). Mandibles moderately enlarged, left mandible somewhat larger, basal halves robust, apical halves forming long thin hook, dorsal side flat, even and glabrous, sides covered with pale setae. Labrum transverse with rounded anterior angles and shallowly emarginated anterior margin, margins except middle of anterior margin covered with short pale setae, surface lustrous with transverse stripe of dense punctures bearing longer pale setae. Clypeus with wide shallow V-shaped anterior margin. Eyes small. Frons very wide, 3.7 times as wide as diameter of eye, surface uneven, irregularly covered with small punctures and long pale setae. Frons separated from vertex by shallow indistinct impression. Vertex lustrous, covered with sparse punctures and pale setae. Antennae short, 0.21 times as long as body, antennomere I club-shaped, II small, globular, III small, triangular, IV triangular with produced apical angle, antennae shortly serrated from antennomere $\mathrm{V}$.

THorax. Pronotum glabrous, lustrous, almost impunctate, 1.74 times as wide as long, widest at basal half, moderately convex. Anterior margin nearly straight, lateral margins rounded, posterior margin slightly rounded and moderately expanded in scutellar area. Anterior angles obtusangulate, posterior angles widely rounded. Lateral and posterior margins bordered, anterior margin bordered only near anterior angles. Posterior angles slightly elevated above elytral base. Scutellum subtriangular with rounded tip, glabrous, in basal quarter punctate, rest of surface impunctate, scutellar apex slightly elevated upon elytral level.
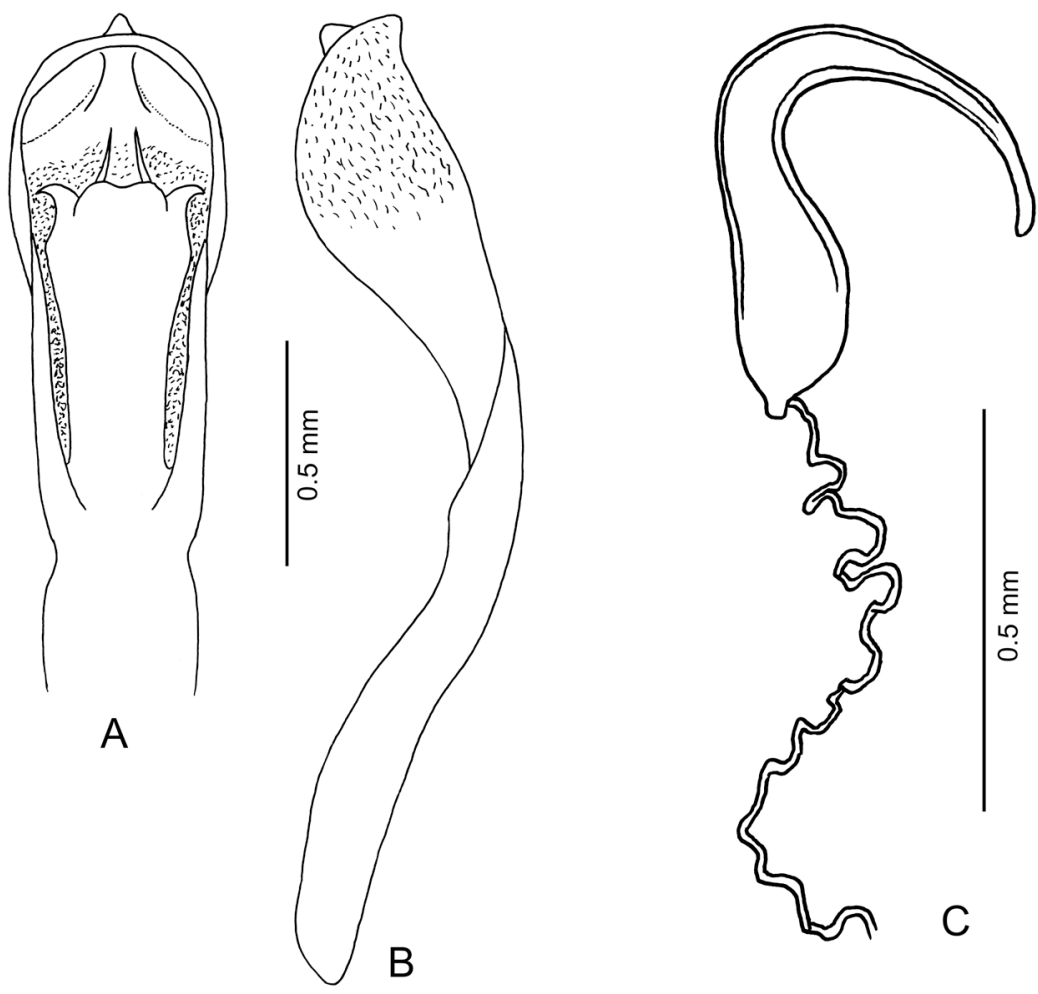

Fig. 5. Melitonoma decemnotata (Thunberg, 1787) comb. nov. A. Aedeagus, dorsal view. B. Aedeagus, lateral view. C. Spermatheca. 
ElYTRA. Subcylindrical, 0.65 times as long as body, 1.54 times as long as wide at humeral part, glabrous, semiopaque, densely covered with small confused punctures, disappearing at elytral apices. Basal margin with complete thin border forming narrow elevated keel. Epipleura impunctate, glabrous, wide basally, suddenly narrowed and disappearing at basal third.

Legs. Protibiae slightly prolonged. Protarsomere I parallel with convergent base, twice as long as broad, length ratios of protarsomeres I-IV equal to 10-7-6-6. Metatarsi narrower that protarsi, length ratios of metatarsomeres I-IV equal to 10-6-6-7. Claws simple.

Male genitalia (Fig 5A-B). Aedeagus narrow, 5.5 times as long as wide. Ventral side bulbous in apical part, covered with fine wrinkles, subapically with small tooth.

Female (Figs 4A-C, I, 5C). Mandibles and anterior legs not enlarged. Tarsi as wide as in male but moderately shorter, length ratios of protarsomeres I-IV equal to 8-6-6-6. Spermatheca: cornu U-shaped, apical half gradually narrowed to sharp apex, basal half moderately wider, spermathecal duct ca 1.5 times as long as cornu, with ca 15 simple coils (Fig. 5C).

\section{Differential diagnosis}

Although the species of Melitonoma Chevrolat, 1836 are highly variable in colour, the combination of black femora and tarsi with yellow tibiae is very unusual. Similar coloured legs are known only in three species of Melitonoma: M. diligens Weise, 1909 (Congo); M. flavotibialis Bryant, 1959 (Kenya); and $M$. litigiosa (Lacordaire, 1848) (widely distributed in Africa). Several years ago I examined one male syntype of $M$. diligens deposited in NHRS but the aedeagus was not studied. The aedeagi of M. flavotibialis and M. litigiosa are similar to that of $M$. decemnotata comb. nov., including a small ventral tooth near apex (see drawings in Medvedev 1993a). This whole species group requires comprehensive revision and, as a first step, M. decemnotata comb. nov. is described above

\section{Distribution}

RSA (see comments).

\section{Comments}

The type locality was not given in the original description. During my visit to the BMNH in 2017, I found three specimens from the Cape Region which perfectly fit the holotype of Cryptocephalus decemnotatus. As Thunberg personally collected in the Cape and described many new species from this locality, I have no doubt that $C$. decemnotatus was also collected there.

Genus Miopristis Lacordaire, 1848

Miopristis colon (Thunberg, 1787)

Fig. 6

Chrysomela colon Thunberg, 1787: 45, fig. 9 (original description).

Clythra colon - Schoenherr 1808: 345. - Forsberg 1821: 263, 278 (redescription).

Miopristis (Miopristis) colon - Jacoby \& Clavareau 1906: 12 (catalogue). - Clavareau 1913: 29 (catalogue).

\section{Type locality}

Not stated. 


\section{Material examined}

\section{Holotype}

SOUTH AFRICA • + ; type locality not stated (see Comments); “colon. / 12 / Mus. Thunb. [box label, w, h]"; UUZM.

\section{Distribution}

Probably RSA (see comments).

\section{Comments}

Lacordaire (1848) listed Clythra colon among the species not known to him and reported it from "Promont. Bonae Spei" [= Cape of Good Hope] although neither Thunberg (1787) nor Forsberg (1821) provided any type locality. Habitually, Miopristis colon is very similar to many South African Clytrini

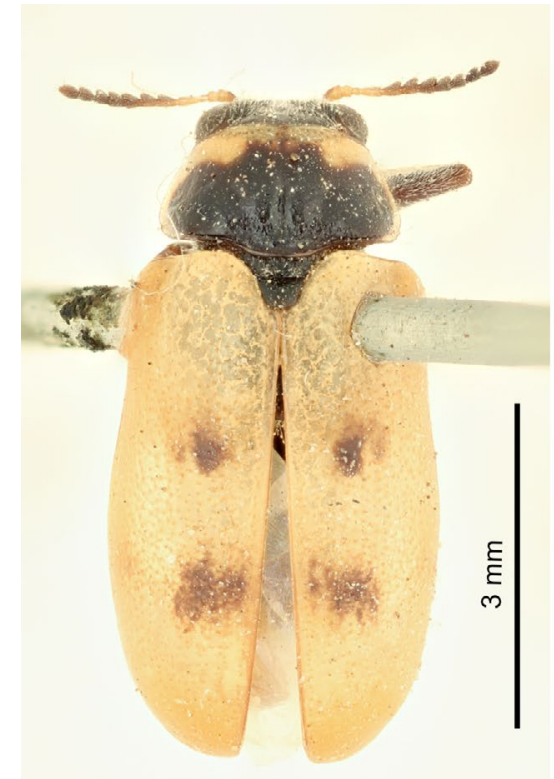

A

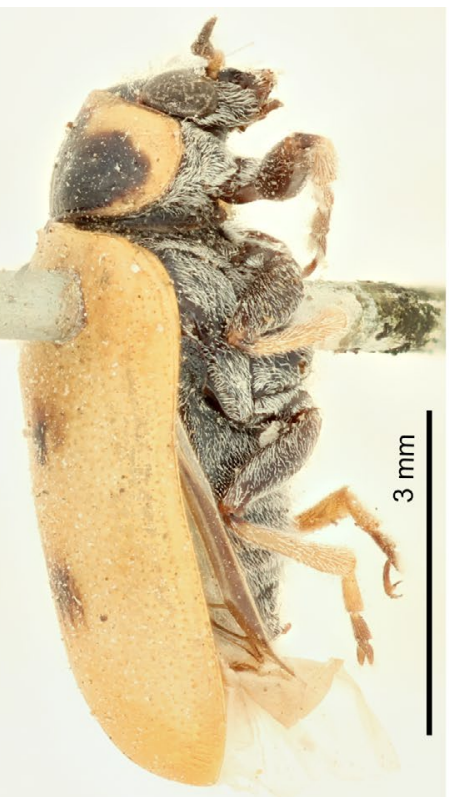

B

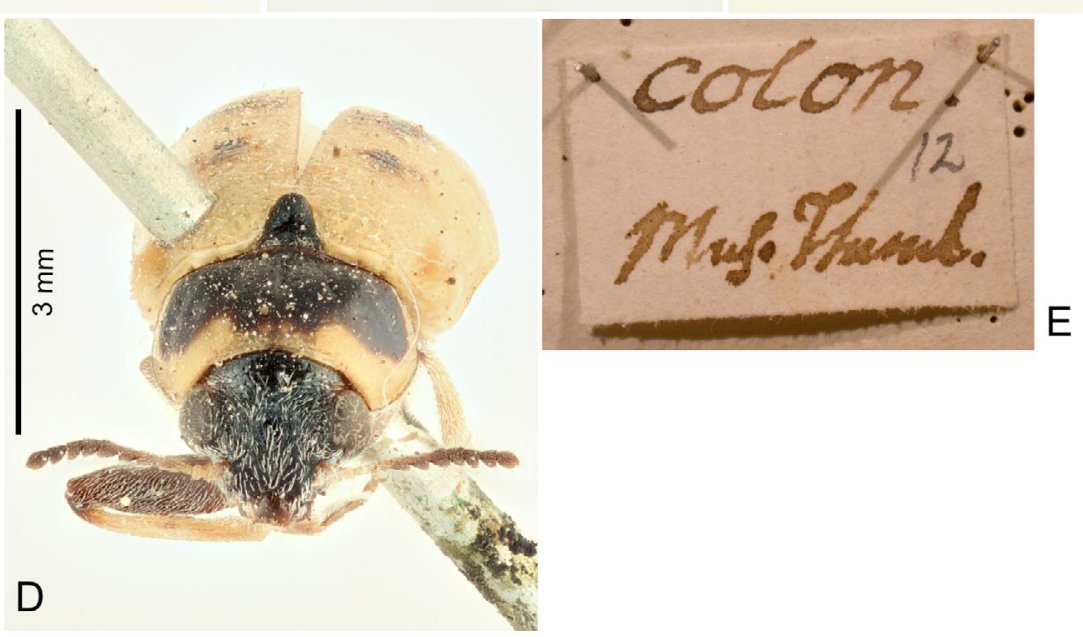

Fig. 6. Miopristis colon (Thunberg, 1821), holotype,,$+ 5.5 \mathrm{~mm}$, UUZM. A. Dorsal view. B. Lateral view. C. ventral view. D. Frontal view. E. Box label. 
which, in accordance with Lacordaire (1848), allows me to believe that the holotype was collected in the Cape together with many other specimens during Thunberg's expeditions.

The holotype of Chrysomela colon was not traced, or was overlooked, by Wallin \& Wallin (2001) and thus it lacks the typical printed red label they added to all type specimens.

The species identity of Chrysomela colon is unclear. The holotype is a relatively small female $(5.5 \mathrm{~mm})$ with a reduced black elytral pattern. Jacoby \& Clavareau (1906) and Clavareau (1913) classified it in Miopristis with some doubt. Currently, the genus Miopristis comprises more than 20 species and I examined the primary type specimens of about $90 \%$ of the species. The colouration of Chrysomela colon does not exactly fit with any of the described species. However, as in many Clytrini, the colouration of species of Miopristis is extremely variable and I cannot exclude that the holotype of Ch. colon is a pale specimen with reduced black pattern of some other already described species. In summary, I leave Chrysomela colon as a valid species in Miopristis, and its identity can be resolved in the future if more specimens, including males, are discovered.

Miopristis flexuosa (Thunberg, 1821)

Fig. 7

Clythra flexuosa Thunberg, 1821: 184 (original description).

Miopristis namaquensis Medvedev, 1993b: 21 (original description). Syn. nov.

Clythra flexuosa - Forsberg 1821: 269, 288 (redescription). — Lacordaire 1848: 393.

Miopristis flexuosa - Gemminger \& Harold 1874: 3280 (catalogue).

Miopristis (Miopristis) flexuosa - Jacoby \& Clavareau 1906: 12 (catalogue). — Clavareau 1913: 29 (catalogue).

\section{Type localities}

Clythra flexuosa: "Cap" [= from the publication title]. Miopristis namaquensis: "South Africa, Richtersveld, Kubosa settlement (28.27 $\left.\mathrm{S}, 17.43^{\circ} \mathrm{E}\right)$ ".

\section{Material examined}

Holotype

SOUTH AFRICA • +; "Uppsala Univ. Zool. Mus. / Thunbergsaml. nr. 8233 / Clythra flexuosa / Cap. TYP [r, p] // flexuosa. / Cap. 12 [box label, w, h]”; UUZM.

\section{Additional material}

SOUTH AFRICA - Northern Cape - $\widehat{\jmath}$ (photograph), paratype of Miopristis namaquensis; "S. Afr., Namaqualand / Eselsfontein / 29.42 S - 17.43 E [w, p] // 16-17.9.1984; 460 m / yellow Comp. \& Acacia / leg. C. L. Bellamy [w, p] // Miopristis / m. / namaquensis [h] / L. N. Medvedev det. 19 [p] 90 [w, h] // PARATYPUS [r, p]"; LMRM. - Western Cape • 1 ภ, 1 ค; Calvinia Nat. Res.; 1000 m a.s.1.; 25 Sept. 1984; W. Wittmer leg.; NHMB.

\section{Distribution}

RSA.

\section{Comments}

Lacordaire (1848) listed Clythra flexuosa as a species unknown to him and speculated that it could belong to the genus Macrolenes Chevrolat, 1836. Subsequent catalogues include this species in the genus Miopristis 
(Jacoby \& Clavareau 1906; Clavareau 1913). Based on the examination of the holotype, I can confirm its position in Miopristis. Moreover, I examined the photograph of a male paratype of M. namaquensis and two additional specimens of M. namaquensis deposited in NHMB, identified by Dieter Erber. Undoubtedly, M. namaquensis is conspecific with M. flexuosa, and thus the new synonymy is proposed.

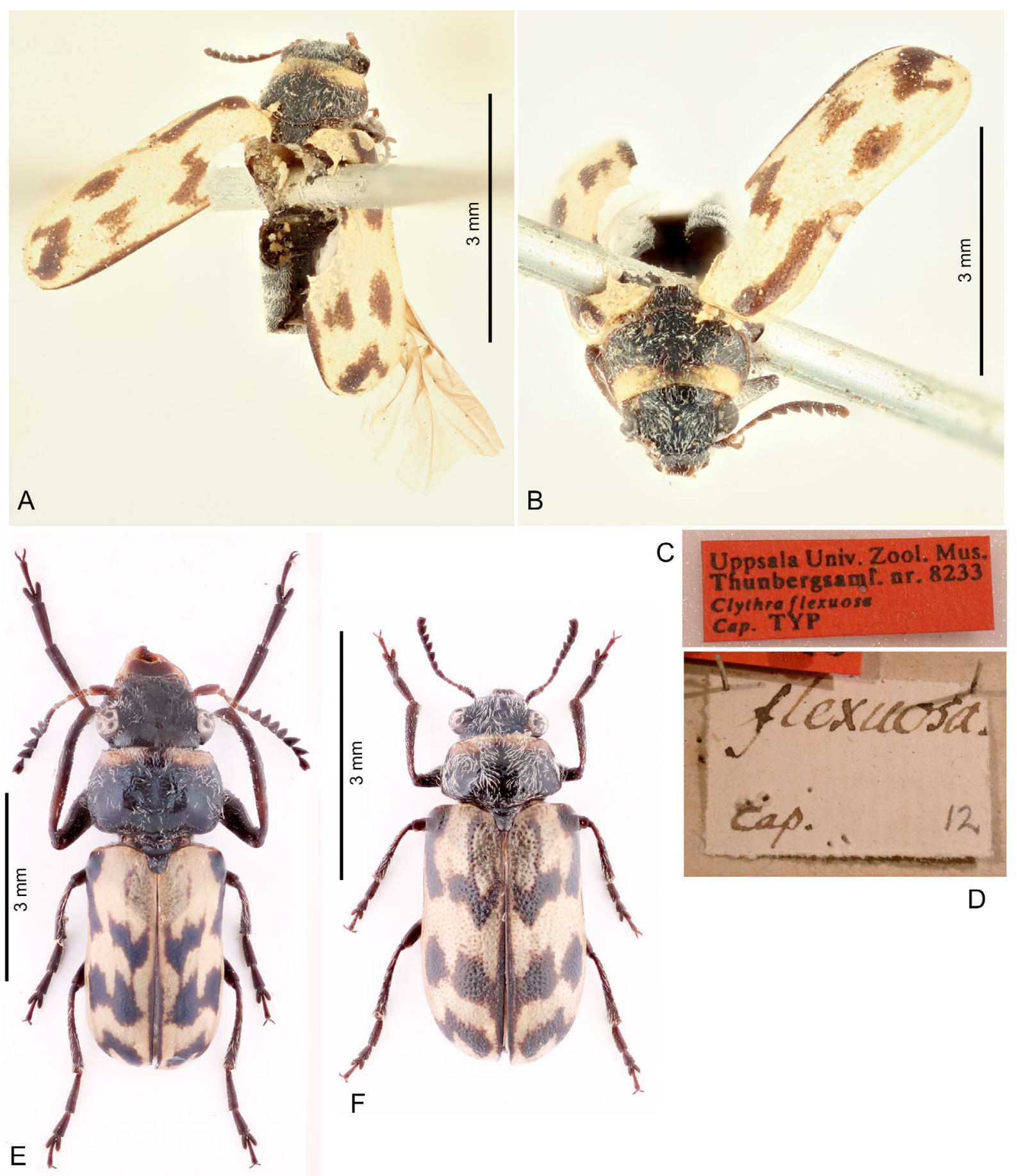

Fig. 7. Miopristis flexuosa (Thunberg, 1787). A-D. Holotype, $q, 4.5 \mathrm{~mm}$, UUZM. A. Dorsal view. B. Frontal view. C. Label. D. Box label. E. ${ }^{7}, 7.0$ mm, RSA, Calvinia Nat. Res., NHMB. F., , 4.7 mm, RSA, Calvinia Nat. Res., NHMB. 
Miopristis stigma (Thunberg, 1821)

Fig. 8

Clythra stigma Thunberg, 1821: 184 (original description).

Clythra stigma - Forsberg 1821: 276 (redescription).

Miopristis stigma - Gemminger \& Harold 1874: 3278 (catalogue).

Miopristis (Miopristis) stigma - Jacoby \& Clavareau 1906: 12 (catalogue). - Clavareau 1913: 29 (catalogue).

\section{Type locality}

"Cap" [= from the publication title].

\section{Material examined}

Holotype

SOUTH AFRICA • \; "Uppsala Univ. Zool. Mus. / Thunbergsaml. nr. 8190 / Clythra stigma / Cap. TYP [r, p] // stigma. / Cap. 6 [box label, w, h]"; UUZM.

\section{Distribution}

RSA.

\section{Comments}

Only the holotype is known, whose head and pronotum are broken and artificially stuck back together. The generic assignment was not clearly understood by the subsequent authors. While Lacordaire (1848) mentioned

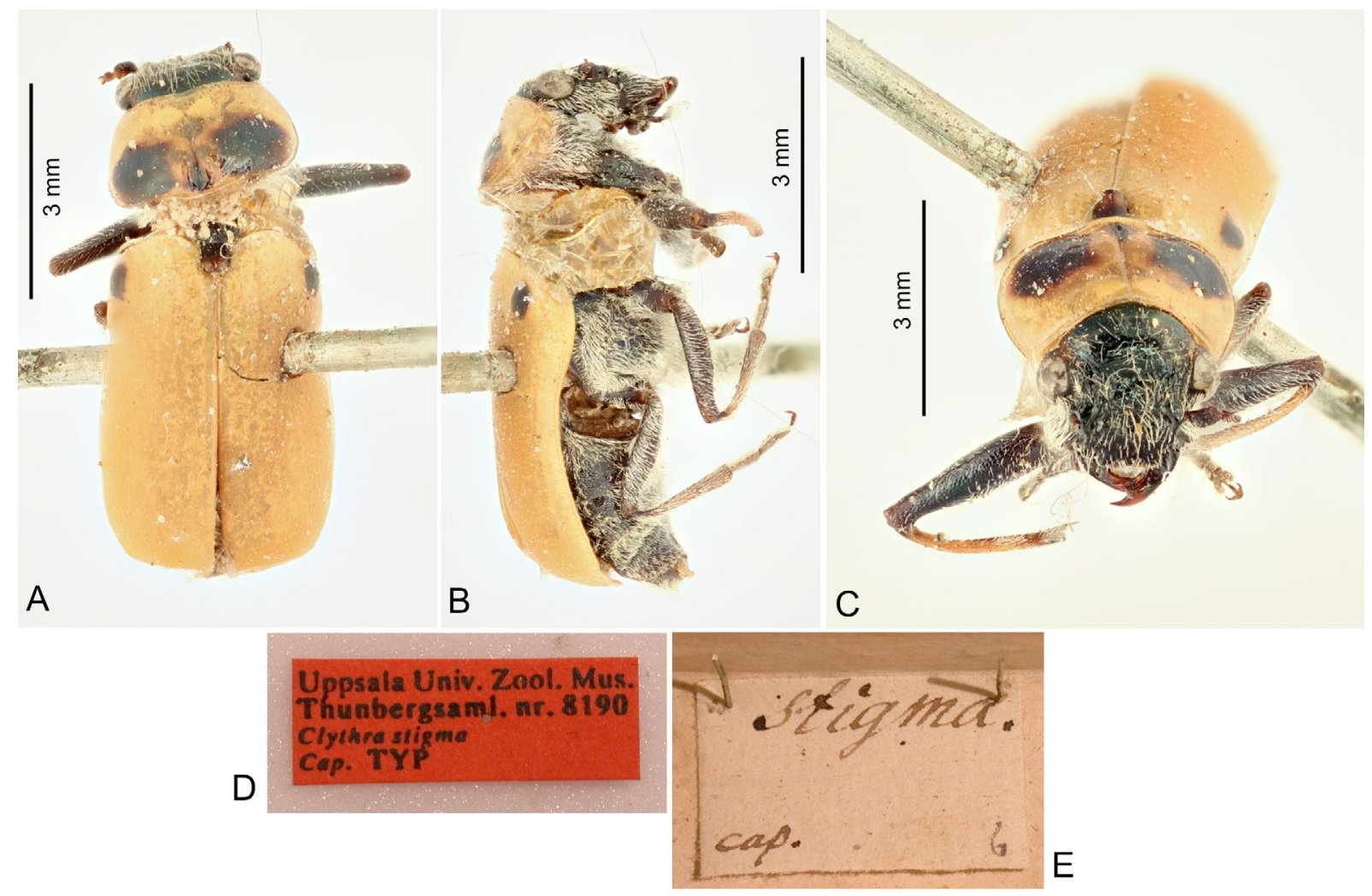

Fig. 8. Miopristis stigma (Thunberg, 1821), holotype, ô, $7.0 \mathrm{~mm}$, UUZM. A. Dorsal view. B. Lateral view. C. Frontal view. D. Label. E. Box label. 
Clythra stigma among the species unknown to him, Gemminger \& Harold (1874) classified it in Miopristis. Jacoby \& Clavareau (1906) and Clavareau (1913) followed the assignment to Miopristis with doubts.

The examination of the holotype showed very densely pubescent propleura. Based on the keys to identification of clytrine genera with pubescent propleurae (Medvedev 1970, 1989a), Clythra stigma should be classified in Protoclytra. Here I have to point out that there is evident confusion in the definition of the genera Miopristis and Protoclytra. Medvedev (1970,1989a) did not include Miopristis in his keys to clytrine genera with pubescent propleurae, which could lead to the assumption that species of Miopristis have the propleura bare. However, the type species Miopristis lepida (Lacordaire, 1848) has the propleura pubescent, which I verified from the type specimen deposited in the BMNH. Also Medvedev (1993b, 1993c) himself mentioned pubescent propleura in the descriptions of Miopristis namaquensis Medvedev, 1993 and Miopristis dimorphus Medvedev, 1993. As the generic relationships between Miopristis and Protoclytra still require further studies, I tentatively leave Clythra stigma in Miopristis.

Genus Plecomera Lacordaire, 1848

Plecomera thunbergii thunbergii (Lacordaire, 1848)

Fig. 9

Clythra (Plecomera) thunbergii Lacordaire, 1848: 104 (replacement name for Clythra macropus Thunberg, 1821, not Clytra macropus Illiger, 1800).

Clythra macropus Thunberg, 1821: 184 (original description).

Clythra (Plecomera) quadraticollis Lacordaire, 1848: 105 (original description).

Clythra macropus - Forsberg 1821: 282 (redescription).

Miopristis macropus - Gemminger \& Harold 1874: 3280 (catalogue).

Miopristis (Plecomera) macropus - Jacoby \& Clavareau 1906: 14 (catalogue).

Miopristis (Plecomera) thunbergi - Clavareau 1913: 31 (catalogue).

\section{Type localities}

Clythra macropus: "Cap" [= from the publication title]. Clythra quadraticollis: "Cap de Bonne Espèrance".

\section{Material examined}

SOUTH AFRICA • 1 §ิ, syntype of Clythra macropus; "Uppsala Univ. Zool. Mus. / Thunbergsaml. nr. 8245 / Clythra macropus / Cap. TYP [r, p] // macropus. / Cap. 24 [box label, w, h]"; UUZM • 1 , syntype of Clythra macropus; "Uppsala Univ. Zool. Mus. / Thunbergsaml. nr. 15375 / Clythra macropus / TYP [r, p] // macropus. / III [box label, w, h]"; UUZM • 1 o, syntype of Clythra quadraticollis; "E. Coll. / Chevt. [w, p] // cbs [w, h] // 240 [b, p] // SYN- / TYPE [round white label with blue collar] // Plecomera / quadraticollis / Lac. type [w, h] // brachialis / Ch. cbs [w, h] // 67-56 [w, p]"; BMNH - 1 ô, syntype of Clythra quadraticollis; "23098 [w, p] // Promont. / b. sp. / Lichtst. [b, h] // Plecomera / quadraticollis / Lacord * [w, h] // Captans / N. / Pr. b. Sp. Lichtenst. [b, h]”; ZMHB.

\section{Distribution}

RSA.

\section{Comments}

Given that Clythra macropus Thunberg, 1821 was a homonym of Clytra macropus Illiger, 1800 (now in Tituboea), Lacordaire (1848) proposed the replacement name Clythra (Plecomera) thunbergii for Thunberg's species. 
Lacordaire (1848) proposed the subgenus Plecomera for two species from the Cape: Clythra thunbergii Lacordaire, 1848 and Clythra quadraticollis Lacordaire, 1848. Recently, Plecomera was treated at genus level by Medvedev (1989b, 1992a, 1993b, 2008) and Medvedev \& Regalin (1997) without any other comment. The type species Clythra quadraticollis was designated by Medvedev \& Regalin (1997). Currently, Plecomera includes six species and one subspecies. However, the position of some species in Plecomera needs verification and the whole genus is in need of comprehensive revision.
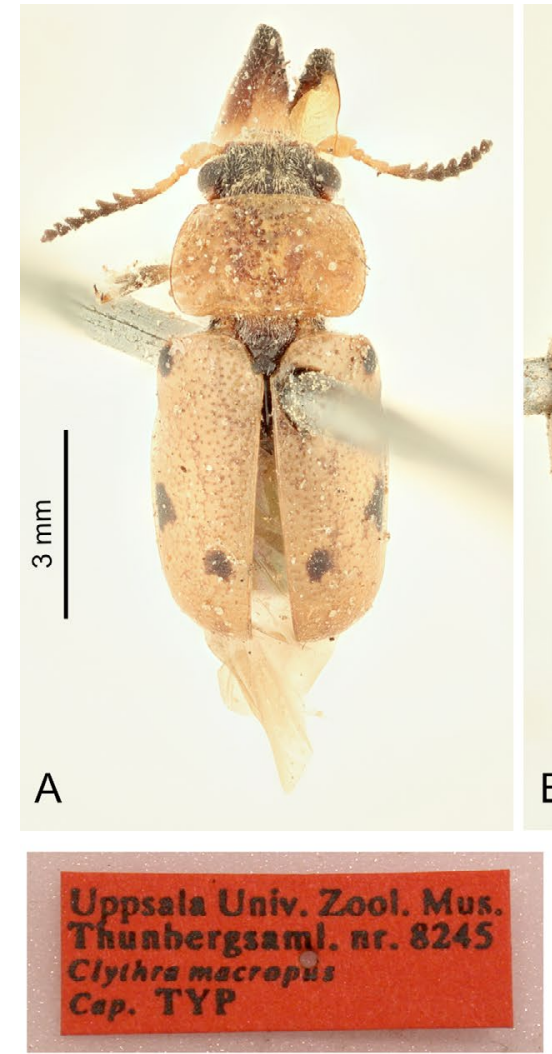

$\mathrm{D}$

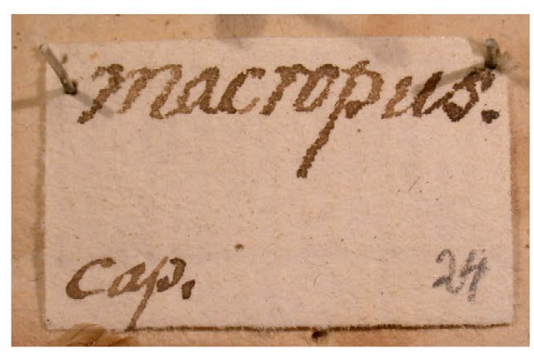

$\mathrm{E}$

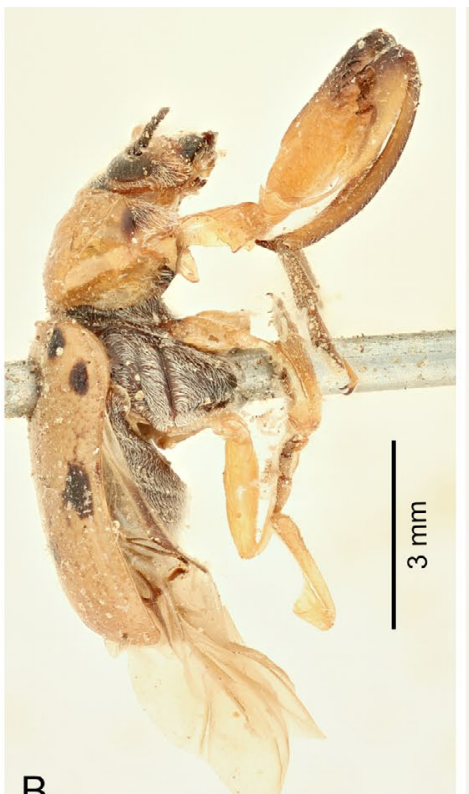

B

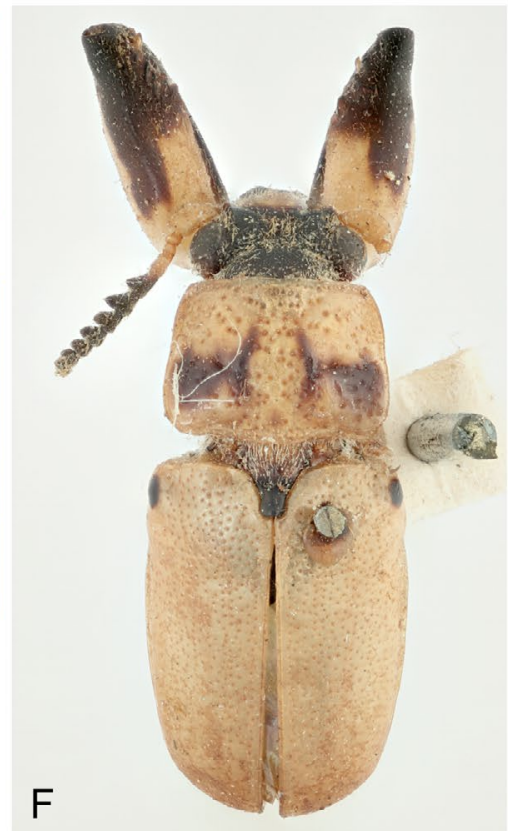

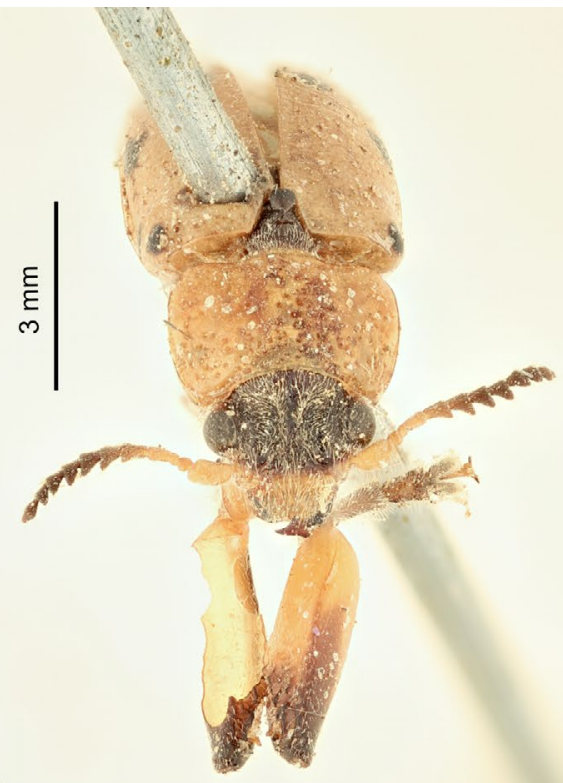

C

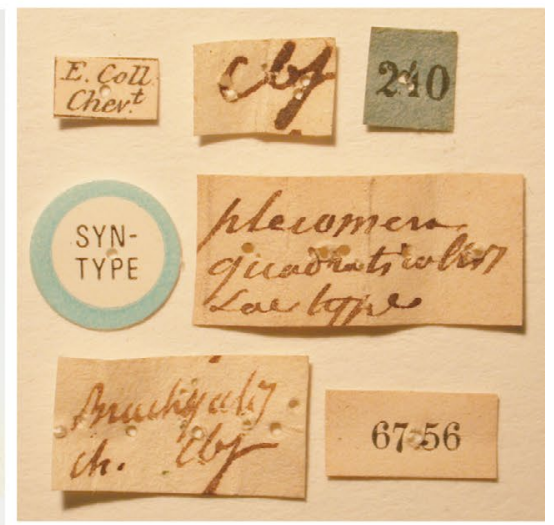

G

Fig. 9. Plecomera thunbergii thunbergii (Lacordaire, 1848). A-E. Syntype of Clythra macropus Thunberg, 1821, ô, 7.5 mm, UUZM. A. Dorsal view. B. Lateral view. C. Frontal view. D. Label. E. Box label. F-G. Syntype of Clythra quadraticollis Lacordaire, 1848, §̂, not measured, BMNH. F. Dorsal view. G. Labels. 
Medvedev (2008) synonymized Plecomera thunbergii and P. quadraticollis arguing that the two taxa represent two extreme color variations of a single species, and he also described transitional forms.

Genus Phoenicodera Lacordaire, 1848

Phoenicodera scapularis (Thunberg, 1821)

Fig. 10

Clythra scapularis Thunberg, 1821: 184 (original description).

Clythra scapularis - Forsberg 1821: 262, 275 (redescription).

Clythra (Phoenicodera) scapularis - Lacordaire 1848: 94.

Tituboea scapularis - Gemminger \& Harold 1874: 3282 (catalogue).
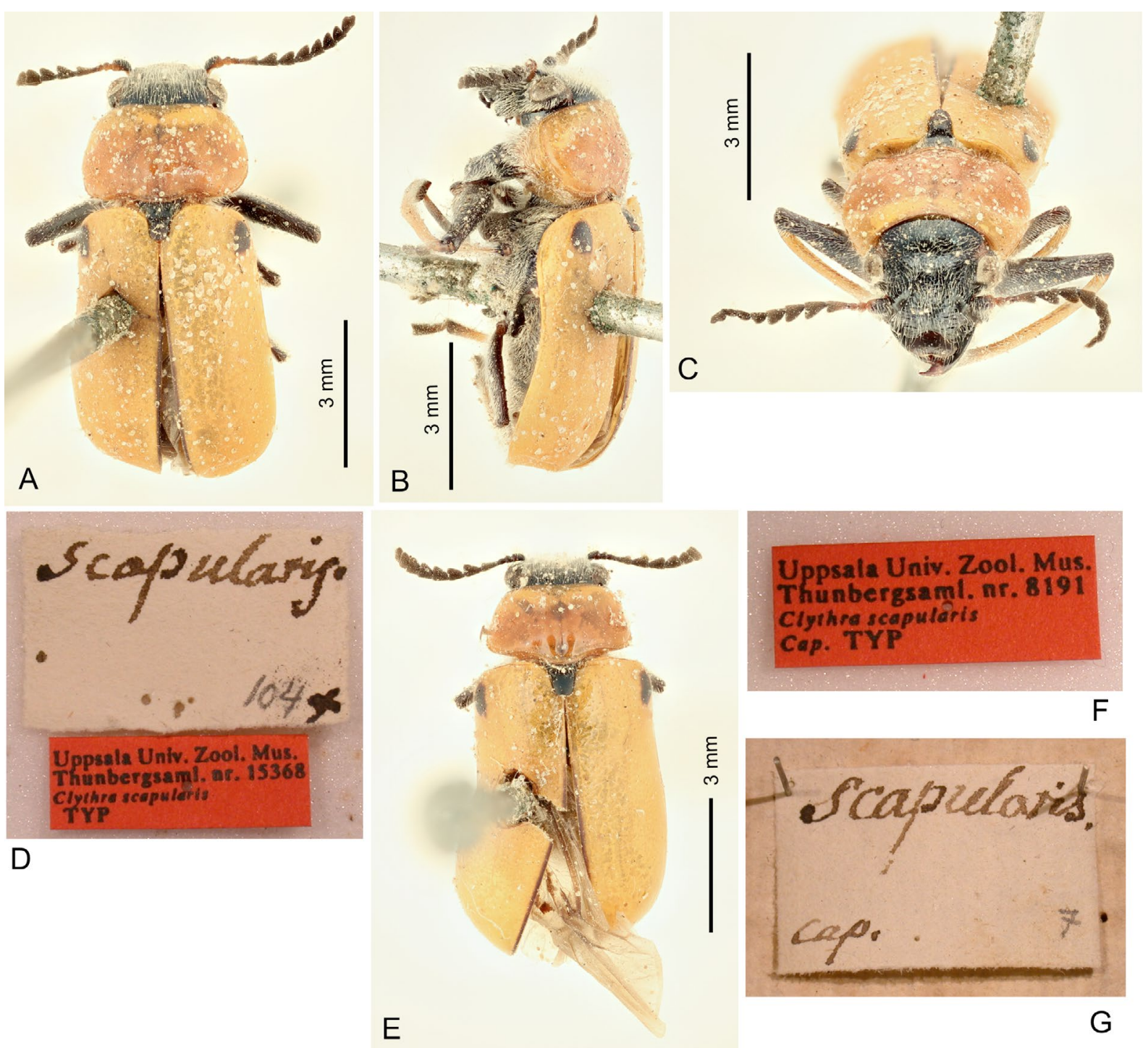

$\mathrm{D}$

E

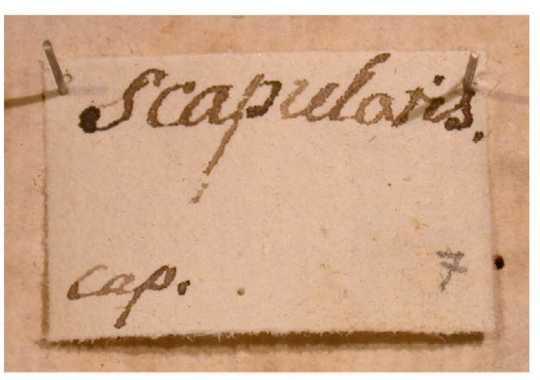

G

Fig. 10. Phoenicodera scapularis (Thunberg, 1821). A-D. Syntype, ðึ, $9.0 \mathrm{~mm}$, UUZM. A. Dorsal view. B. Lateral view. C. Frontal view. D. Label and box label. E-G. Syntype, + , 7.8 mm, UUZM. E. Dorsal view. F. Label. G. Box label. 
Tituboea (Phoenicodera) scapularis - Jacoby \& Clavareau 1906: 24 (catalogue).

Antipa (Phoenicodera) scapularis - Clavareau 1913: 440 (catalogue).

\section{Type locality}

"Cap" [= from the publication title].

\section{Material examined}

\section{Syntypes}

SOUTH AFRICA • 1 đ̊; "Uppsala Univ. Zool. Mus. / Thunbergsaml. nr. 15368 / Clythra scapularis / TYP [r, p] // scapularis. / 104 [box label, w, h]"; UUZM・ 1 +, "Uppsala Univ. Zool. Mus. / Thunbergsaml. nr. 8191 / Clythra scapularis / Cap. TYP [r, p] // scapularis. / Cap. 7 [box label, w, h]”; UUZM.

\section{Distribution}

RSA.

\section{Comments}

The genus Phoenicodera was originally proposed as a subgenus of Clythra by Lacordaire (1848), who included two species: Clythra scapularis Thunberg, 1821 and Clythra varicollis Lacordaire, 1848. Subsequent authors catalogued Phoenicodera as a subgenus of either Tituboea or Antipa. Medvedev (1993b) raised Phoenicodera to genus level, but without any comments.

Phoenicodera clearly needs modern revision. In particular, its relationships with the genera Tituboea and Antipus need clarification. To my knowledge the type species of Phoenicodera was not designated. However, I will avoid doing that without performing a comprehensive revision of the genus. Currently, five species are classified in Phoenicodera: the two abovementioned, Phoenicodera robusta Medvedev, 1993 (from RSA), P. metallica Pic, 1939 and P. nigrovittata Pic, 1939 (both from Angola). Medvedev (1993b) keyed three South African species.

Genus Protoclytra Weise, 1905

Protoclytra (Lacordairella) taeniata (Thunberg, 1821) comb. nov.

Fig. 11

Clythra taeniata Thunberg, 1821: 184 (original description).

Clythra (Camptolenes) fastuosa Lacordaire, 1848: 113 (original description). Syn. nov.

Clythra taeniata - Forsberg 1821: 287 (redescription).

Clythra (Camptolenes) taeniata - Lacordaire 1848: 117.

Lachnaea taeniata - Gemminger \& Harold 1874: 3281 (catalogue).

Crabronites (Camptolenes) taeniata - Jacoby \& Clavareau 1906: 16 (catalogue). — Clavareau 1913: 32 (catalogue).

Camptolenes taeniata - Medvedev \& Erber 2003: 86 (misidentification ?).

Lachnaea (Camptolenes) fastuosa - Chapuis 1874: 114.

Lachnaea fastuosa - Gemminger \& Harold 1874: 3281 (catalogue).

Crabronites (Camptolenes) fastuosa - Jacoby \& Clavareau 1906: 16 (catalogue). — Clavareau 1913: 32 (catalogue).

Protoclytra (Lacordairella) fastuosa - Medvedev 1970: 194. 


\section{Type localities}

Clythra taeniata: "Cap" [= from the publication title]. Clythra (Camptolenes) fastuosa: "Afrique australe" [= Southern Africa].

\section{Material examined}

\section{Holotype}

SOUTH AFRICA • ○’; "Uppsala Univ. Zool. Mus. / Thunbergsaml. nr. 8232 / Clythra taeniata / Cap. TYP [r, p] // catenata. / Cap. 11 [box label, w, h]"; UUZM.

\section{Additional material}

SOUTH AFRICA • $\hat{\jmath}$, syntype of Clythra (Camptolenes) fastuosa; "23101 [w, p] // Caffraria / Krebs [blue-grey, h] // Camptolenes / fastuosa Lac. * [w, h] // fastuosa / N. / Caffr. Krebs. [b, h]”; ZMHB.

\section{Distribution}

RSA.
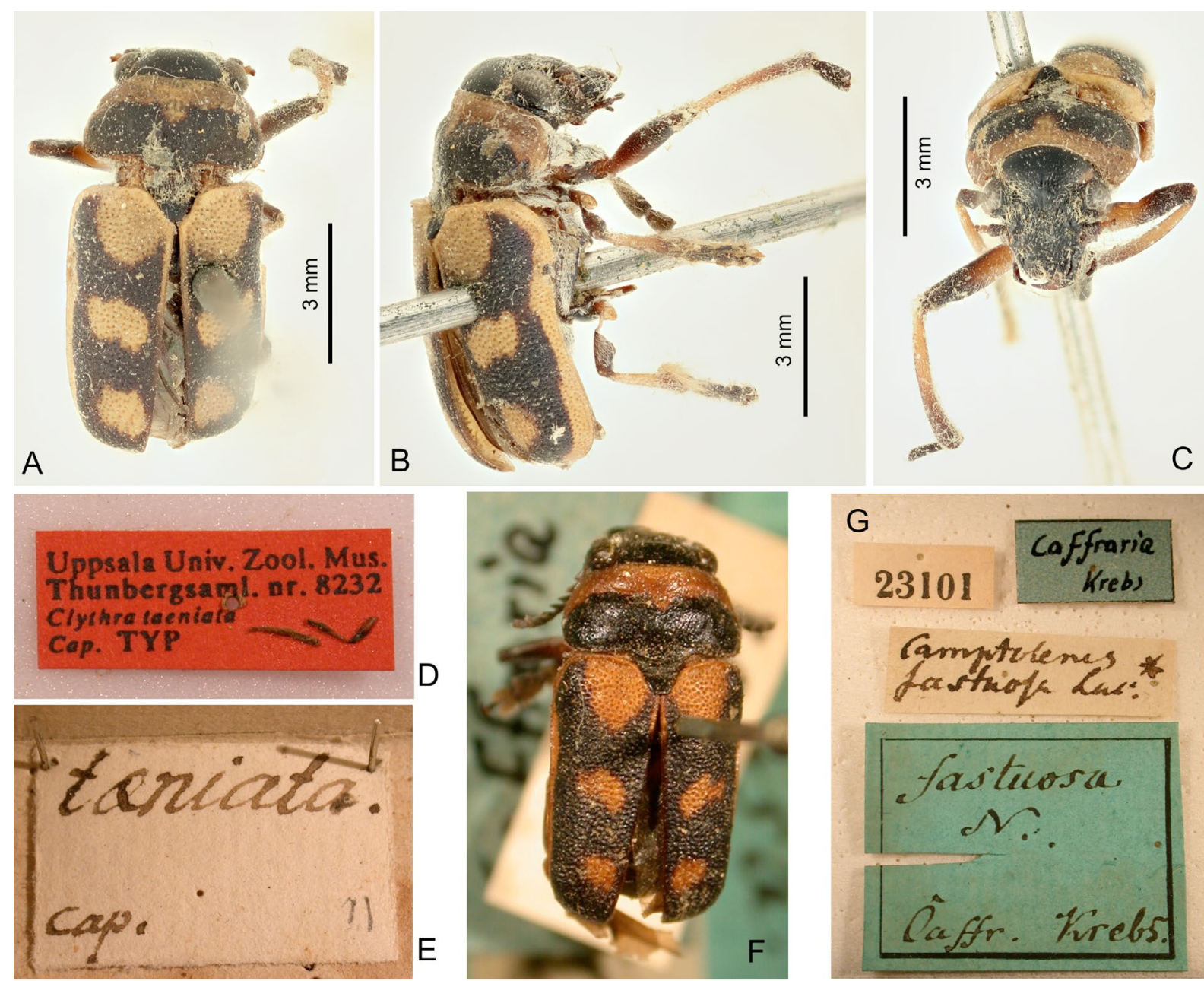

Fig. 11. Protoclytra taeniata (Thunberg, 1821) comb. nov. A-E. Holotype, $\widehat{\jmath}, 8.0 \mathrm{~mm}$, UUZM. A. Dorsal view. B. Lateral view. C. Frontal view. D. Label. E. Box label. F-G. Syntype of Clythra fastuosa Lacordaire, 1848, §, not measured, ZMHB. F. Dorsal view. G. Labels. 


\section{Comments}

Lacordaire (1848) classified both Clythra taeniata and C. fastuosa in Camptolenes, a subgenus of Clytra. Having been the generic name Camptolenes Chevrolat, 1836 originally used for a different species (now a synonym of Clytra Laicharting, 1781, see Bousquet \& Bouchard 2013), Monrós (1953) proposed the generic name Lacordairella Monrós, 1953 for the Camptolenes species sensu Lacordaire (1848) and designated Clythra fastuosa as the type species of Lacordairella. Later, Medvedev (1970) downgraded Lacordairella to subgenus of Protoclytra.

The comparison of the holotype of Clythra taeniata with the syntype of Clythra fastuosa deposited in ZMHB undoubtedly showed both taxa to be conspecific. Consequently, Clythra fastuosa is proposed as a new synonym of Protoclytra (Lacordairella) taeniata comb. nov.

Medvedev \& Erber (2003) discussed the elytral colour pattern variability of Camptolenes taeniata, however, their drawings do not fit well with the elytral colouration of the holotype. I cannot exclude that Medvedev \& Erber (2003) misidentified the studied specimens.

Currently, Protoclytra subgenus Lacordairella includes eight species, six of them were listed by Medvedev (1970). Two additional species were also described by Medvedev (1993a, 1993d). No keys to species of Lacordairella have ever been provided.

Genus Smeia Lacordaire, 1848

Smeia undata (Thunberg, 1821) comb. nov.

Fig. 12

Clythra undata Thunberg, 1821: 184 (original description).

Clythra (Smeia) virginea Lacordaire, 1848: 24 (original description). Syn. nov.

Melitonoma pictipennis Jacoby, 1898: 350 (original description). Syn. nov.

Clythra undata - Forsberg 1821: 288 (redescription). — Lacordaire 1848: 393.

Miopristis undata - Gemminger \& Harold 1874: 3280 (catalogue).

Miopristis virginea - Gemminger \& Harold 1874: 3280 (catalogue).

Melitonoma pictipennis - Medvedev 1979: 170 (= Smeia virginea).

\section{Type localities}

Clythra undata: "Cap" [= from the publication title]. Clythra (Smeia) virginea: "Caffrerie". Melitonoma pictipennis: "Pretoria".

\section{Material examined}

Holotype

SOUTH AFRICA • \; "Uppsala Univ. Zool. Mus. / Thunbergsaml. nr. 8234 / Clythra undata / Cap. TYP [r, p] // catenata. / Cap. 13 [box label, w, h]"; UUZM.

\section{Additional material}

SOUTH AFRICA, Western Cape • $\widehat{0}$, syntype of Clythra (Smeia) virginea; "23051 [w, p] // Promont. / b. sp. / Krebs [blue-grey, h] // Smeia / virginea Lac. * [w, h] // Hist.-Coll. (Coleoptera) / Nr. 23051 / Smeia virginea Lac. x / Promont. b. sp. Krebs / Zool. Mus. Berlin [b, p] // Smeia / virginea Lac. [h] / L. Medvedev det. 96 [p] 7 [w, h] // SYNTYPE / Smeia virginea / Lacordaire, 1848 / labelled by MFNB 2017 [r, p]"; ZMHB • 1 q. "Promont. b. sp." [= Promontorio Bonae Spei]; Krebs leg.; ZMHB. Gauteng 1 1 , syntype of Melitonoma pictipennis; "SYN- / TYPE [white round label with blue collar, 
p] // Pretoria / (W. L. D.) [w, p] // Distant Coll. / 1911-383 [w, p] // Melitonoma / pictipennis / Jac. [b, h] // Smeia / virginea Lac. [h] / L. N. Medvedev det. 19 [p] 68 [w, h]"; BMNH • 1 +, syntype of Melitonoma pictipennis; "SYN- / TYPE [white round label with blue collar, p] // Pretoria / (W. L. D.) [w, p] // Jacoby Coll. / 1909-28a [w, p] // Melitonoma / pictipennis / Jac. [b, h]”; BMNH •

\section{Distribution}

RSA.

\section{Comments}

The identity of Clythra undata was unclear to the subsequent authors. Lacordaire (1848) listed C. undata among the species not known to him but, based on the description, he speculated its position within the

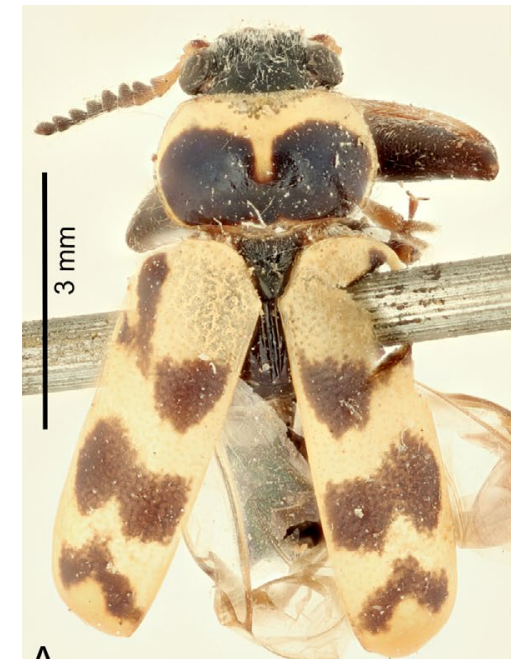

A

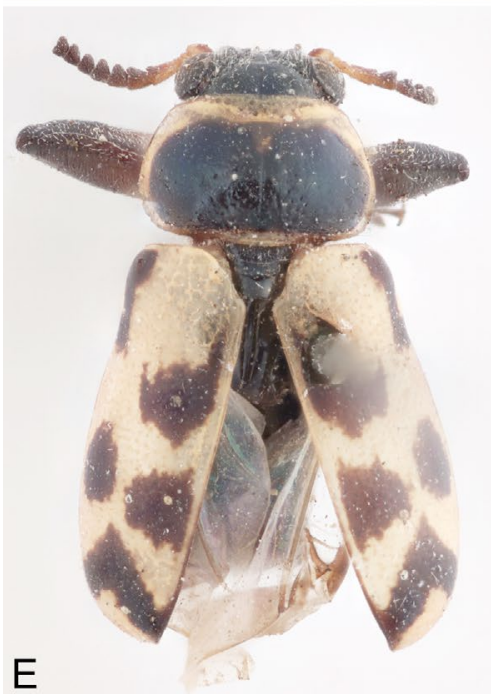

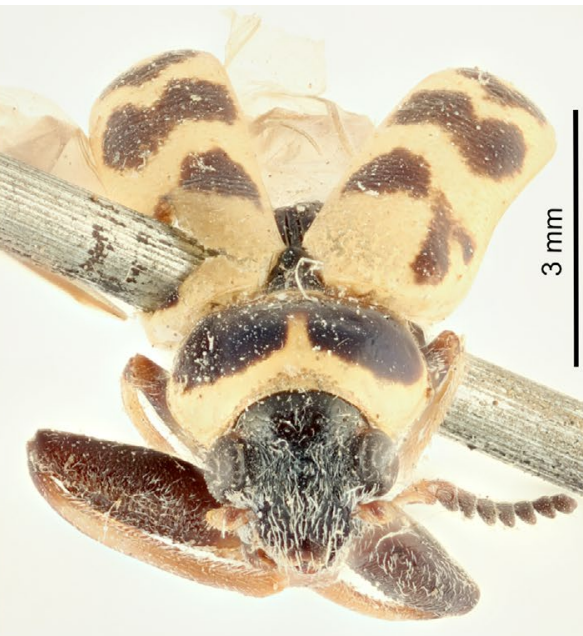

B

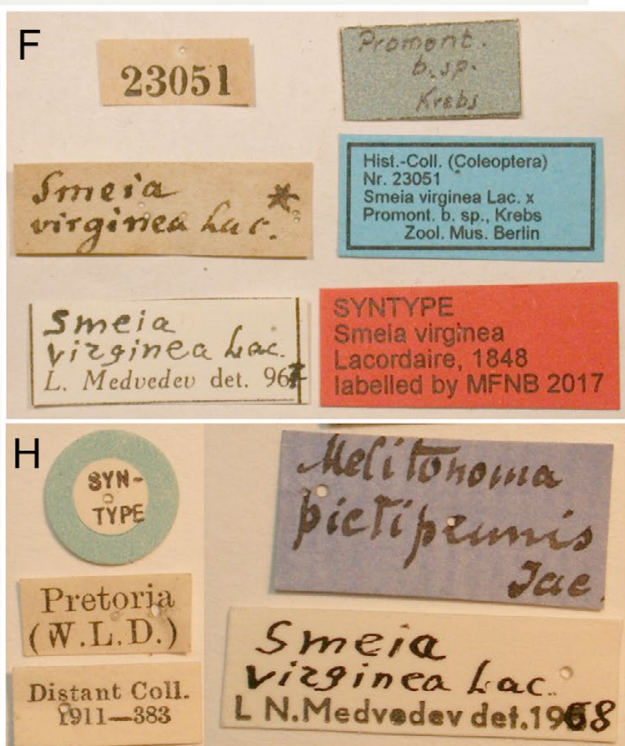

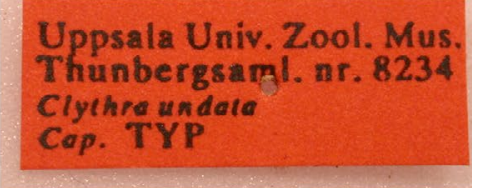

C

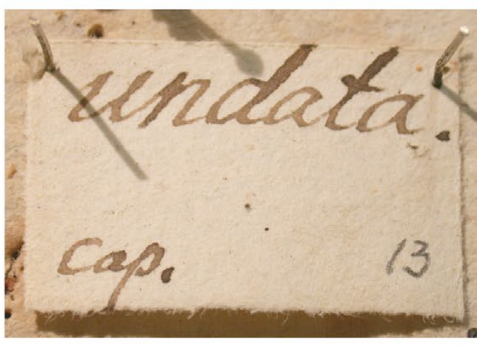

D

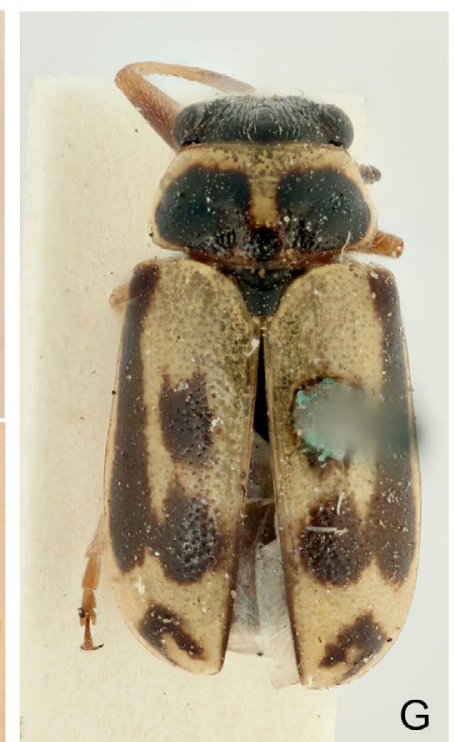

Fig. 12. Smeia undata (Thunberg, 1821) comb. nov. A-D. Holotype, $\widehat{\jmath}, 6.5 \mathrm{~mm}$, UUZM. A. Dorsal view. B. Frontal view. C. Label. D. Box label. E-F. Syntype of Clythra virginea Lacordaire, 1848, ô, not measured, ZMHB. E. Dorsal view. F. Labels. G-H. Syntype of Melitonoma pictipennis Jacoby, 1898, , , not measured, BMNH. G. Dorsal view. H. Labels. 
genus Macrolenes. In the catalogues by Gemminger \& Harold (1874), Jacoby \& Clavareau (1906) and Clavareau (1913), it is classified in the genus Miopristis.

The comparison of the primary type specimens of Clythra undata, C. virginea and Melitonoma pictipennis showed that all three taxa are conspecific, and they are therefore synonymized here. Medvedev (1979) synonymized Melitonoma pictipennis Jacoby, 1898 with Smeia virginea without any comments. Melitonoma pictipennis was described from two females now deposited in BMNH. Both specimens have the outer elytral black spots connected, forming a lateral black stripe. Except for this colour peculiarity, I do not see any other difference.

Lacordaire (1848) did not specify the number of available specimens when describing Smeia virginea, only mentioning material from Caffrerie deposited in "Museum Berlin". Based on the catalogue of this historic collection, the original series included three specimens (Jäger 2017, pers. comm.) and I was able to locate two of them: a male and a female. Because Lacordaire (1848) explicitly mentioned that the female was unknown to him, I treat only the male as a syntype, the female is listed here in the section 'Additional material examined'.

The genus Smeia Lacordaire, 1848 is among the genera with pubescent propleura and can be distinguished by the combination of the following characters: epipleura glabrous, male fore legs elongate with strongly thickened femora, anterior margin of elytra elevated along whole length, antennomere IV elongate, pronotum glabrous (see the generic keys by Medvedev 1970, 1989a). Currently, only two species are classified in Smeia: S. undata comb. nov. and S. braunsi Medvedev, 1993, both distributed in RSA. Smeia braunsi differs from $S$. undata comb. nov. in apex of aedeagus bulbous and carinate underside, and missing humeral and preapical elytral spots (Medvedev 1993a).

Genus Teinocera Lacordaire, 1848

Teinocera catenata (Thunberg, 1821) comb. nov.

Fig. $13 \mathrm{~A}-\mathrm{D}$

Clythra catenata Thunberg, 1821: 184 (original description).

Clythra (Lophobasis) subclathrata Lacordaire, 1848: 20 (original description) (not examined). Syn. nov.

Clythra (Miopristis) catenata - Lacordaire 1848: 28.

Miopristis catenata - Gemminger \& Harold 1874: 3280 (catalogue). — Papp 1951: 83 (key). Medvedev 1979: 170; 1989b: 776.

Miopristis (Miopristis) catenata - Jacoby \& Clavareau 1906: 12 (catalogue). - Clavareau 1913: 29 (catalogue).

\section{Type localities}

Clythra catenata: "Cap" [= from the publication title]. Clythra (Lophobasis) subclathrata: "Caffrerie".

\section{Material examined}

Holotype

SOUTH AFRICA • O'; “Uppsala Univ. Zool. Mus. / Thunbergsaml. nr. 8229 / Clythra catenata / Cap. TYP [r, p] // catenata. / Cap. 8 [box label, w, h]”; UUZM.

\section{Distribution}

RSA. 


\section{Comments}

One type specimen of Clythra (Lophobasis) subclathrata, originally deposited in ZMHB, was not located (Jäger 2017, pers. comm.).

The holotype of Clythra catenata is a representative of the genus Teinocera Lacordaire, 1848. The identity of Clythra catenata has a long history of misinterpretation. Lacordaire (1848) classified it in Miopristis Lacordaire, 1848, and this placement was followed by all subsequent authors (Gemminger \& Harold 1874; Jacoby \& Clavareau 1906; Clavareau 1913; Papp 1951; Medvedev 1979, 1989b).

Males of Teinocera subclathrata are characterised by the last antennomere divided by an indistinct suture into a larger basal part and a thin apical part. The same character was observed in the holotype of Clythra catenata. Although one type specimen of Teinocera subclathrata originally deposited in ZMHB was not traced there (Jäger 2017, pers. comm.), its original description agrees well with the species definition in various collections. As a result, Clythra catenata is transferred to Teinocera, and T. subclathrata is proposed as new synonym.

The genus Teinocera Lacordaire, 1848 currently contains five species. Three species were keyed by Medvedev (1992a) and two additional species were described by Erber \& Medvedev (2002).

Medvedev (1979) synonymized Labidostomis insidiosa Péringuey, 1888 with Miopristis catenata. I had the possibility to study photographs of two syntypes of Labidostomis insidiosa deposited in SAMC, and at first glance the two taxa are not congeneric. Labidostomis insidiosa is restored as a valid species in Miopristis; however, its placement in Miopristis needs further study as the definition of Miopristis is not stabilized.

Subfamily Synetinae LeConte \& Horn, 1883

Genus Syneta Dejean, 1835

Syneta betulae (Fabricius, 1792) nomen protectum

Fig. $13 \mathrm{E}-\mathrm{G}$

Crioceris betulae Fabricius, 1792: 5 (original description) (not examined).

Crioceris betulina Thunberg, 1787: 47 (original description) nomen oblitum

\section{Type localities}

Crioceris betulae: "Lapponiae". Crioceris betulina: "Lapponia".

\section{Material examined}

\section{Syntypes}

COUNTRY UNKNOWN • 1 spec. unsexed; "Uppsala Univ. Zool. Mus. / Thunbergsaml. nr. 9507 / Crioceris betulina / Mus. Thunb. TYP [r, p] // betulina. / $4 \alpha$. / Mus. Thunb. [box label, w, h]"; UUZM - 1 spec. unsexed; "Uppsala Univ. Zool. Mus. / Thunbergsaml. nr. 15253 / Crioceris betulina / TYP [r, p] // betulina. / $\gamma$. / $103 \times$ x [w, h]"; UUZM.

\section{Comments}

Two syntypes of Crioceris betulina deposited in UUZM are conspecific with Syneta betulae betulae (Fabricius, 1792). In order to preserve stability, according to Art. 23.9 of ICZN (1999) I propose to consider Crioceris betulina as nomen oblitum and Syneta betulae betulae (Fabricius, 1792) as nomen protectum. The conditions of the Article 23.9.1.1 are met because to my knowledge the name Crioceris betulina has not been used as valid in any publication after 1899. Following Article 23.9.1.2, I supply 
the references of 25 papers, published by at least 10 authors in the immediately preceding 50 years and encompassing a span of not less than 10 year, where Syneta betulae is treated as a valid species: Leiler (1973), Medvedev \& Zaitsev (1978), Mann \& Crowson (1981, 1983), Medvedev (1982, 1992b, 2012), Dubeshko \& Medvedev (1989), Lee (1990), Schawaller (1990), Medvedev \& Dubeshko (1992), Samuelson (1994), Telnov \& Kalniņš (2003), Warchałowski (2003, 2010), Bienkowski (2004),
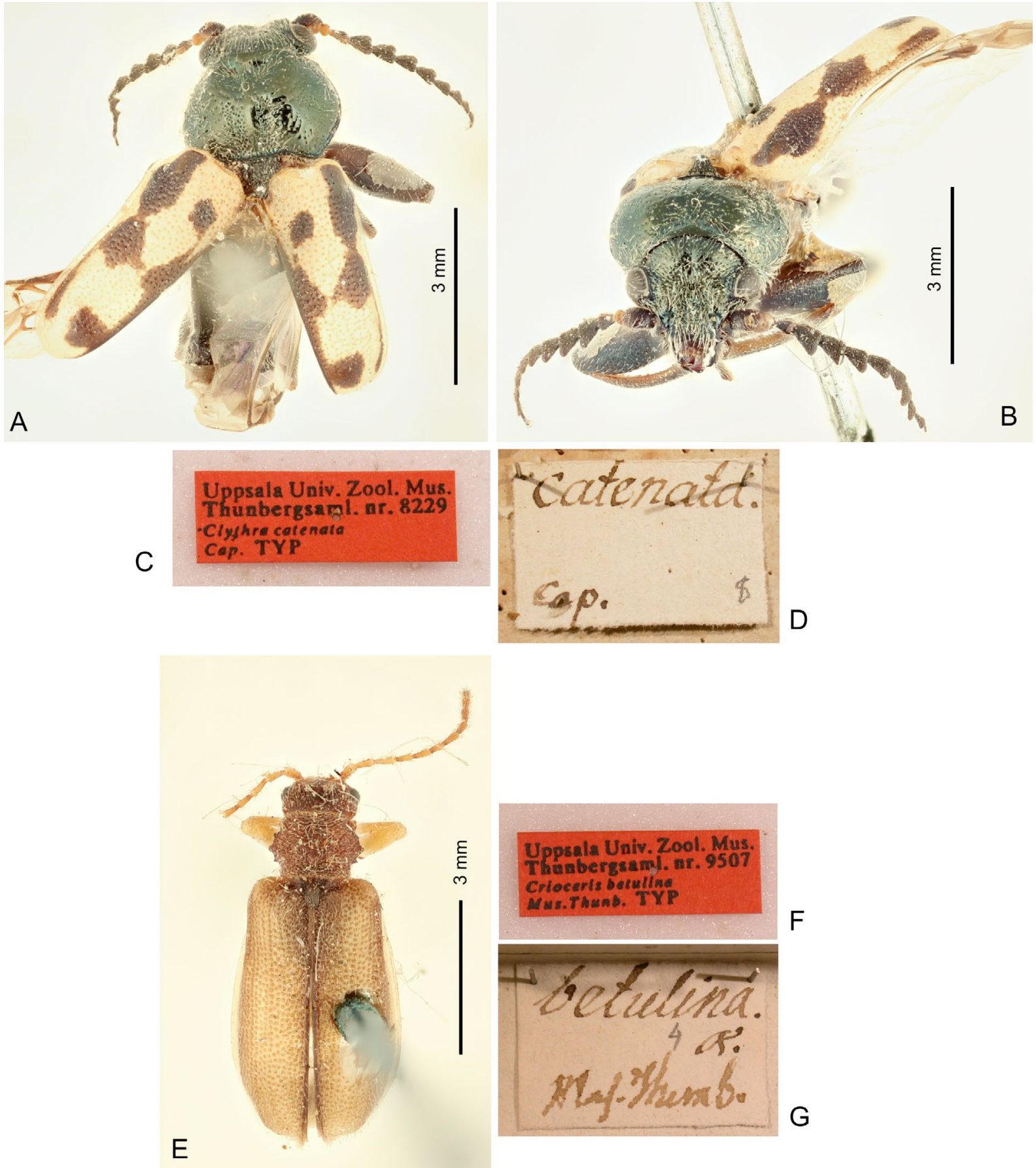

Fig. 13. A-D. Holotype of Teinocera catenata (Thunberg, 1821) comb. nov., §ิ, $6.7 \mathrm{~mm}$, UUZM. A. Dorsal view. B. Frontal view. C. Label. D. Box label. E-G. Syneta betulae (Fabricius, 1792) (syntype of Crioceris betulina Thunberg, 1787, unsexed, $6.0 \mathrm{~mm}$, UUZM). E. Dorsal view. F. Label. G. Box label. 
Silfverberg (2004, 2010a, 2010b), Telnov (2004), Jolivet \& Verma (2008), Guskova (2010), Bukejs (2012, 2013), Lawrence \& Ślipiński (2014).

Subfamily Galerucinae Latreille, 1802

Genus Exosoma Jacoby, 1903

Exosoma lusitanica (Linnaeus, 1767)

Fig. 14A-D

Chrysomela lusitanica Linnaeus, 1767: 1066 (original description) (not examined).

Crioceris haemorrhoa Thunberg, 1827: 7 (original description). Syn. nov.

For a full list of synonyms, see Beenen (2010).

\section{Type localities}

Chrysomela lusitanica: "Lusitania". Crioceris haemorrhoa: "Cap" [= from the title, probably erroneous, see Comments below].

\section{Material examined}

COUNTRY UNKNOWN (see Comments) • $\widehat{O}$, holotype of Crioceris haemorrhoa; "Uppsala Univ. Zool. Mus. / Thunbergsaml. nr. 9537 / Crioceris haemorrhoa / Cap. TYP [r, p] // haemorrhoa. / Cap. 7 [box label, w, h]"; UUZM.

\section{Comments}

The holotype of Crioceris haemorrhoa was dissected and is without any doubt conspecific with the common west Mediterranean Exosoma lusitanicum. The type locality "Cap" is evidently incorrect. Very probably the holotype was collected in the Mediterranean area during Thunberg's travels and subsequently mislabelled.

Genus Megalognatha Baly, 1878

Megalognatha festiva (Fabricius, 1781)

Fig. 14E-J

Cistela festiva Fabricius, 1781: 148 (original description).

Apophylia elegantula Jacoby, 1891: 39 (original description) (not examined).

Crioceris virens Thunberg, 1827: 10 (original description). Syn. nov.

\section{Type localities}

Cistela festiva: "Cap. bon. sp.". Apophylia elegantula: "South Africa". Crioceris virens: "Cap" [= from the publication title].

\section{Material examined}

\section{Holotype}

SOUTH AFRICA • +; “Type / H. T. [white round label with red collar] // Cist. Festiva / Fabr. Sp. Ins. n. 13 [w, h] // Dissected on behalf / of B. Grobbelar S. Africa [h] / S. L. Shute det. 19 [p] 89 [w, h] // Megalognatha / festiva (F.) [h] / S. L. Shute det. 19 [p] 89 / = elegantula Jac / not elegans Baly. [w, h] // AfriGa / specimen ID: [p] / 1512 [h] / specimen data / documented [p] / 15.II. [h] 20 [p] 05. [g, h]”; BMNH. 


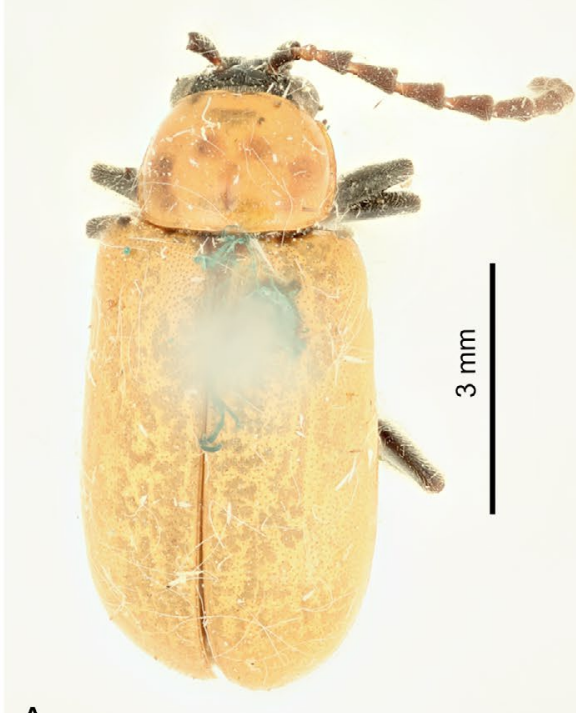

A
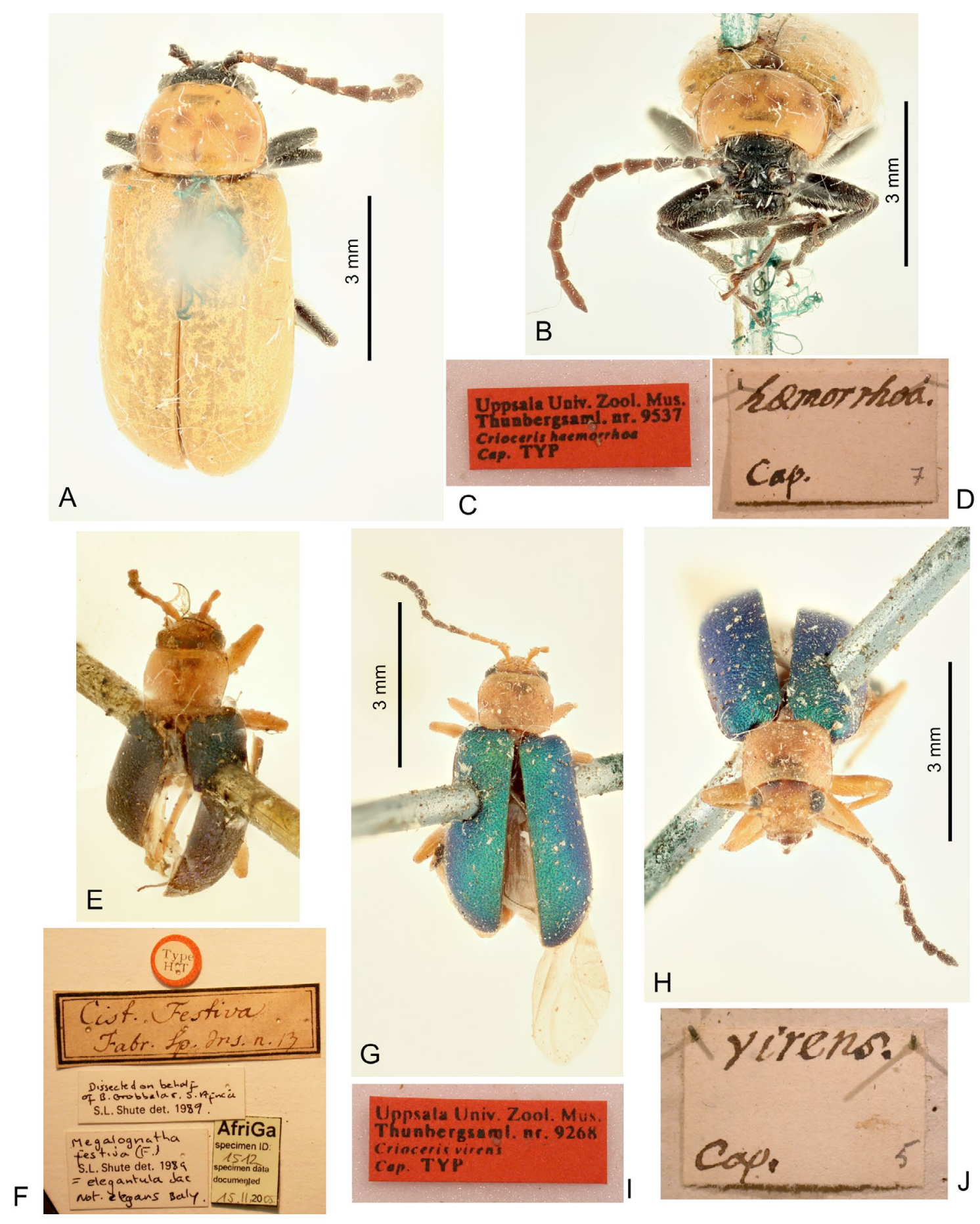

Fig. 14. A-D. Exosoma lusitanica (Linnaeus, 1767), holotype of Crioceris haemorrhoa Thunberg, 1827, ô, 8.0 mm, UUZM. A. Dorsal view. B. Frontal view. C. Label. D. Box label. E-J. Megalognatha festiva (Fabricius, 1781). E-F. Holotype of Cistela festiva Fabricius, 1781, $q$, not measured, BMNH. E. Dorsal view. F. Labels. G-J. Holotype of Crioceris virens Thunberg, 1827, ㅇ, 4.5 mm, UUZM. G. Dorsal view. H. Frontal view. I. Label. J. Box label. 


\section{Additional material}

SOUTH AFRICA • + , holotype of Crioceris virens; "Uppsala Univ. Zool. Mus. / Thunbergsaml. nr. 9268 / Crioceris virens / Cap. TYP [r, p] // virens. / Cap. 5 [box label, w, h]”; UUZM.

\section{Comments}

Megalognatha festiva was recently redescribed by Grobbelaar (1993). The syntype of Crioceris virens was compared with the Fabrician type specimen of Cistela festiva deposited in the BMNH and without any doubt the two taxa are conspecific. Crioceris virens is proposed as a new synonym of Megalognatha festiva.

\section{Genus Monolepta Chevrolat, 1836}

Monolepta bioculata (Fabricius, 1781)

Fig. 15

Crioceris bioculata Fabricius, 1781: 154 (original description).

Chrysomela 4maculata Goldfuss, 1805: 42 (original description) (not examined).

Cryptocephalus bioculatus Thunberg, 1827: 14 (original description). Syn. nov.

\section{Type localities}

Crioceris bioculata: not stated. Chrysomela quadrimaculata: "Cap. Bon. Spei”. Cryptocephalus bioculatus: "Cap. Bon. Spei”.

\section{Material examined}

Lectotype (designated by Wagner 2007)

SOUTH AFRICA • +; “Crioceris 2-oculata / Fabr. Sp. Ins. n. 27 [w, h] // Lectotypus / Th. Wagner desig. [p] 96 [r, h] // AfriGa / specimen ID: [p] / 936 [h] / specimen data / documented [p] / 15.II. [h] 20 [p] 08. $[\mathrm{g}, \mathrm{h}] " ;$ BMNH - Banks coll.

\section{Paralectotype}

SOUTH AFRICA • +; "Paralectotypus / Th. Wagner desig. [p] 96 [r, h]”; BMNH - Banks coll.

\section{Additional material}

SOUTH AFRICA 1 ㅊ, lectotype of Cryptocephalus bioculatus (designated here); "Uppsala Univ. Zool. Mus. / Thunbergsaml. nr. 9466 / Cryptocephalus bioculatus / Cap. TYP [r, p] // bioculatus. / a. / Cap. 1 x [box label, w, h]"; UUZM 11 +, paralectotype of Cryptocephalus bioculatus (designated here); "Uppsala Univ. Zool. Mus. / Thunbergsaml. nr. 9467 / Cryptocephalus bioculatus / Cap. TYP [r, p] // bioculatus. / $\beta$. / Cap. 2 x [box label, w, h]"; UUZM • 1 o, paralectotype of Cryptocephalus bioculatus (designated here); "Uppsala Univ. Zool. Mus. / Thunbergsaml. nr. 9468 / Cryptocephalus bioculatus / Cap. TYP [r, p] // bioculatus. / $\gamma$. / Cap. 3 x [box label, w, h]”; UUZM • 1 ô, paralectotype of Cryptocephalus bioculatus (designated here); "Uppsala Univ. Zool. Mus. / Thunbergsaml. nr. 9580 / Cryptocephalus bioculatus / Mus. Thunb. TYP [r, p] // bioculatus. / $\alpha$. / Mus. Thunb. 17 [box label, w, h]"; UUZM • 1 o, paralectotype of Cryptocephalus bioculatus (designated here); "Uppsala Univ. Zool. Mus. / Thunbergsaml. nr. 15175 / Cryptocephalus bioculatus / TYP [r, p] // bioculatus. / $\delta . / 25 \mathrm{x}$ [w, h]"; UUZM; 1 \%, paralectotype of Cryptocephalus bioculatus (designated here); "Uppsala Univ. Zool. Mus. / Thunbergsaml. nr. 15501 / Cryptocephalus bioculatus / TYP [r, p] // bioculatus. / $\beta$. / $103 \times$ [w, h]"; UUZM. The type specimens are provided with one printed red label: "LECTOTYPUS, [or PARALECTOTYPUS, resp.] / Cryptocephalus / bioculatus / Thunberg, 1827 / J. Bezděk des., 2018". 


\section{Comments}

Thunberg's collection consists of six syntypes of Cryptocephalus bioculatus, which include three different species. The two specimens (Nos. 9466 and 9580) that best fit the original description are conspecific with Monolepta bioculata. Another specimen (No. 9468) is Monolepta cruciata Guérin
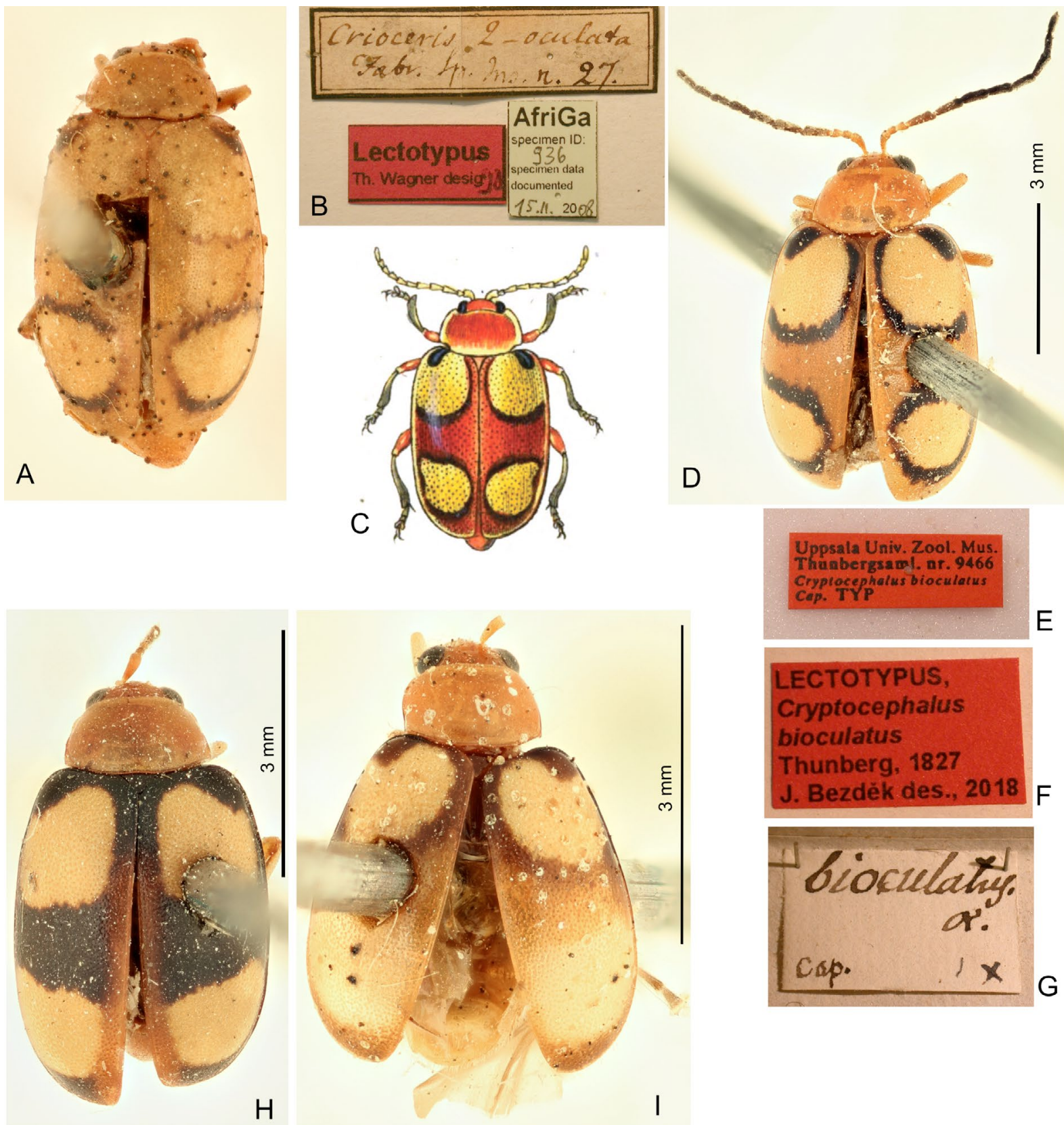

Fig. 15. A-I. Monolepta bioculata (Fabricius, 1781). A-B. Lectotype, $q$, not measured, BMNH. A. Dorsal view. B. Labels. C. Chrysomela quadrimaculata Goldfuss, 1805 (drawing from the original description). D-G. Lectotype of Cryptocephalus bioculatus Thunberg, 1827, §, $5.5 \mathrm{~mm}$, UUZM. D. Dorsal view. E. Label. F. Lectotype label. G. Box label. H. Paralectotype of Cryptocephalus bioculatus Thunberg, 1827, đ, 4.8 mm, UUZM (actually Monolepta cruciata Guérin-Méneville, 1849). I. Paralectotype of Cryptocephalus bioculatus Thunberg, 1827, ô, $4.0 \mathrm{~mm}$, UUZM (actually Monolepta signata (Olivier, 1908)). 
de Méneville, 1847. The last three specimens (Nos. 9467, 15175 and 15501) are Monolepta signata (Olivier, 1808), which were evidently mislabelled, as M. signata is an Asiatic species and its occurrence in southern Africa is improbable. These specimens were probably collected in Java and Thunberg mistakenly mixed them with southern African specimens.

As the type series is composed of three different species, syntype No. 9466 is selected and here designated as the lectotype, and the identity of Cryptocephalus bioculatus Thunberg, 1827 is fixed to one specimen. Due to this act, Cryptocephalus bioculatus is proposed as a new synonym of Monolepta bioculata (Fabricius, 1781). Monolepta bioculata is the type species of the genus Monolepta, and was recently redescribed, including study of the type material, by Wagner (2007).

\section{Monolepta melanogaster (Wiedemann, 1823)}

Fig. 16

Galleruca melanogaster Wiedemann, 1823: 77 (original description) (not examined).

Cryptocephalus capensis Thunberg, 1827: 15 (original description). Syn. nov.

\section{Type localities}

Galleruca melanogaster: "Prom. bon. sp.". Cryptocephalus capensis: "Cap" [= from the publication title].

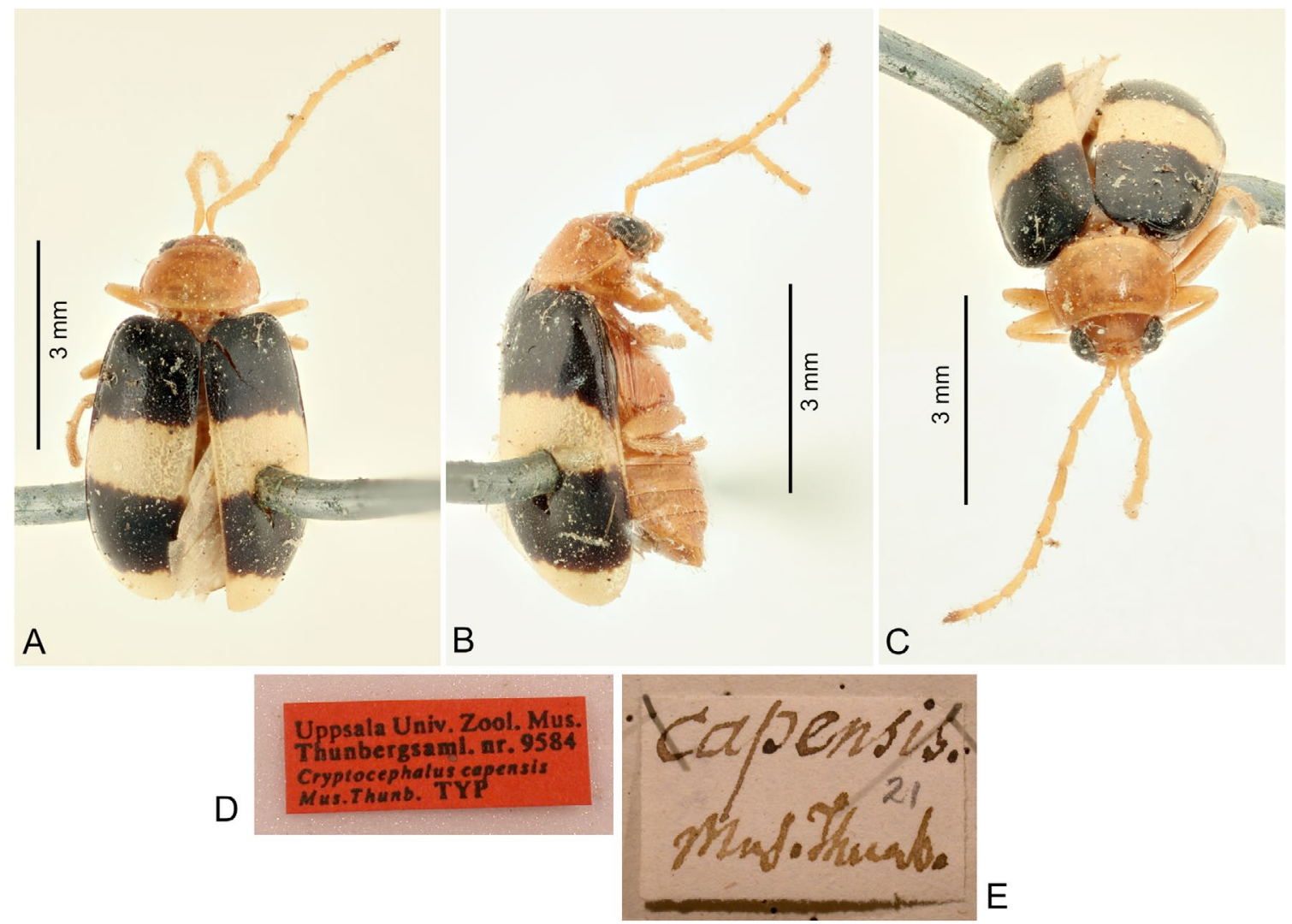

Fig. 16. A-E. Monolepta melanogaster (Wiedemann, 1823) (syntype of Cryptocephalus capensis Thunberg, 1827, đ, 5.0 mm, UUZM). A. Dorsal view. B. Lateral view. C. Frontal view. D. Label. E. Box label. 


\section{Type material examined}

SOUTH AFRICA 1 §’, syntype of Cryptocephalus capensis; "Uppsala Univ. Zool. Mus. / Thunbergsaml. nr. 9584 / Cryptocephalus capensis / Mus. Thunb. TYP [r, p] // capensis. / 21 / Mus. Thunb. [box label, w, h]"; UUZM • 1 + , syntype of Cryptocephalus capensis; "Uppsala Univ. Zool. Mus. / Thunbergsaml. nr. 14734 / Cryptocephalus capensis / Cap. TYP [r, p] // capensis. / 86 x [w, h]”; UUZM.

\section{Comments}

Thunberg's collection consists of two syntypes (male and female) of Cryptocephalus capensis. Without any doubt Cryptocephalus capensis is conspecific with Monolepta melanogaster and the new synonymy is proposed. Monolepta melanogaster was recently redescribed (Wagner 2005).

Genus Palaeophylia Jacoby, 1903

Palaeophylia tricolor (Fabricius, 1781)

Fig. 17

Chrysomela tricolor Fabricius, 1781: 129 (original description).

Crioceris tetrapuncta Thunberg, 1787: 47 (original description). Syn. nov.

Crioceris dimidiata Thunberg, 1827: 9 (original description). Syn. nov.

\section{Type localities}

Chrysomela tricolor: not stated; Crioceris tetrapuncta: "Cap" [= from the publication title]. Crioceris dimidiata: "Cap" [= from the publication title].

\section{Material examined}

\section{Holotype}

SOUTH AFRICA • 1 spec. unsexed; "Chr. Tricolor / Fabr. Sp. Ins. n. 77 [w, h] // AfriGa / specimen ID: [p] / $251[\mathrm{~h}] /$ specimen data / documented [p] / 4.IX. [h] 20 [p] 08. [g, h]”; BMNH - Banks coll.

\section{Additional material}

SOUTH AFRICA • 1 spec. unsexed, syntype of Crioceris tetrapuncta; "Uppsala Univ. Zool. Mus. / Thunbergsaml. nr. 9521 / Crioceris tetrapuncta / Mus. Thunb. TYP [r, p] // tetrapuncta / 15 / Mus. Thunb. [box label, w, h]"; UUZM • 1 spec. unsexed, syntype of Crioceris tetrapuncta; "Uppsala Univ. Zool. Mus. / Thunbergsaml. nr. 9219 / Crioceris tetrapuncta / Cap. TYP [r, p] // tetrapuncta. / Cap. 3 [w, h]"; UUZM -2 specs, lectotype (head and pronotum, designated here) and 1 paralectotype (elytra and thorax) of Crioceris dimidiata; "Uppsala Univ. Zool. Mus. / Thunbergsaml. nr. 9220 / Crioceris dimidiata / Cap. TYP [r, p] // dimidiata. / Cap. 4 [box label, w, h] // LECTOTYPUS, / head and pronotum / Crioceris dimidiata / Thunberg, 1827 / J. Bezděk des., 2018 [r, p] // PARALECTOTYPUS, / elytra and thorax / Crioceris dimidiata / Thunberg, 1827 / J. Bezděk des., 2018 [r, p]”; UUZM.

\section{Comments}

Thunberg's collection in UUZM contains two syntypes of Crioceris tetrapuncta (Fig. 17G). Both specimens were compared with the holotype of Palaeophylia tricolor and the taxa are conspecific. Consequently, Crioceris tetrapuncta is synonymized with Palaeophylia tricolor.

The only known type specimen of Crioceris dimidiata (Fig. 17C) is a composite of two different species, but this does not influence the use of the name (see article 17.1 of the Code). The head and pronotum belong to Palaeophylia tricolor (Fabricius, 1781), while the rest of body originates from a beetle unknown to me (but not Chrysomelidae). As Thunberg's description of Crioceris dimidiata perfectly 
fits the composite specimen, I have no doubt that the specimen was already composite when Thunberg wrote the description. The head and pronotum are designated as the lectotype of Crioceris dimidiata, in order to fix the name to a particular identity, and C. dimidiata is synonymized with Palaeophylia tricolor.

Currently, the genus Palaeophylia Jacoby, 1903 includes nine species (Nie et al. 2017) and Palaeophylia tricolor (Fabricius, 1781) is its type species. The genus was never revised and it seems to be evident that some of the species are not congeneric with Palaeophylia and will be transferred to another genus/other genera in the future.
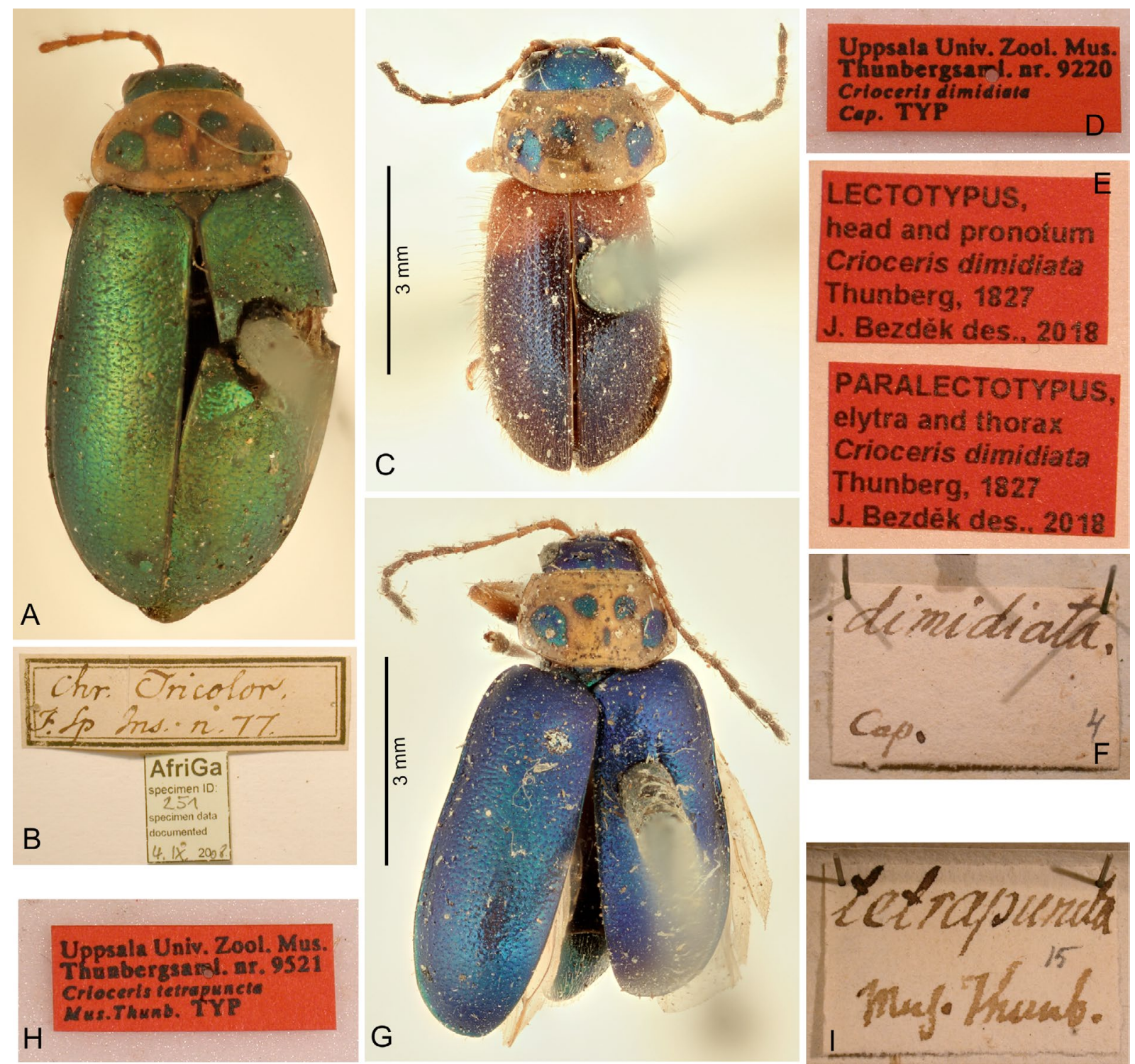

Fig. 17. A-I. Palaeophylia tricolor (Fabricius, 1781). A-B. Holotype, unsexed, not measured, BMNH. A. Dorsal view. B. Labels. C-F. Lectotype/paralectotype of Crioceris dimidiata Thunberg, 1827, unsexed, $6.0 \mathrm{~mm}$, UUZM. C. Dorsal view. D. Label. E. Lectotype and paralectotype labels. F. Box label. G-I. Syntype of Crioceris tetrapuncta Thunberg, 1787, unsexed, $6.5 \mathrm{~mm}$, UUZM. G. Dorsal view. H. Label. I. Box label. 
Genus Taumacera Thunberg, 1814

Taumacera deusta Thunberg, 1814

Fig. 18

Taumacera deusta Thunberg, 1814: 48 (original description).

Oedicerus apicipennis Baly, 1879: 110 (original description).

Nacrea apicipennis Baly, 1886: 29 (original description).

\section{Type localities}

Taumacera deusta: "Goda-Hopps Udden" [= Cap. Bon. Spei; patria falsa]. Oedicerus apicipennis: "India". Nacrea apicipennis: "India" [probably erroneous, see Comments].

\section{Material examined}

\section{Holotype}

INDONESIA • ^’; probably Java (see Comments); "Uppsala Univ. Zool. Mus. / Thunbergsaml. nr. 12377 / Taumacera deusta / Cap. TYP [r, p] // deusta. / Cap. [box label, w, h]”; UUZM.

\section{Additional material}

Oedicerus apicipennis: probably same type specimen as for Nacrea apicipennis (for details see Bezděk 2019).

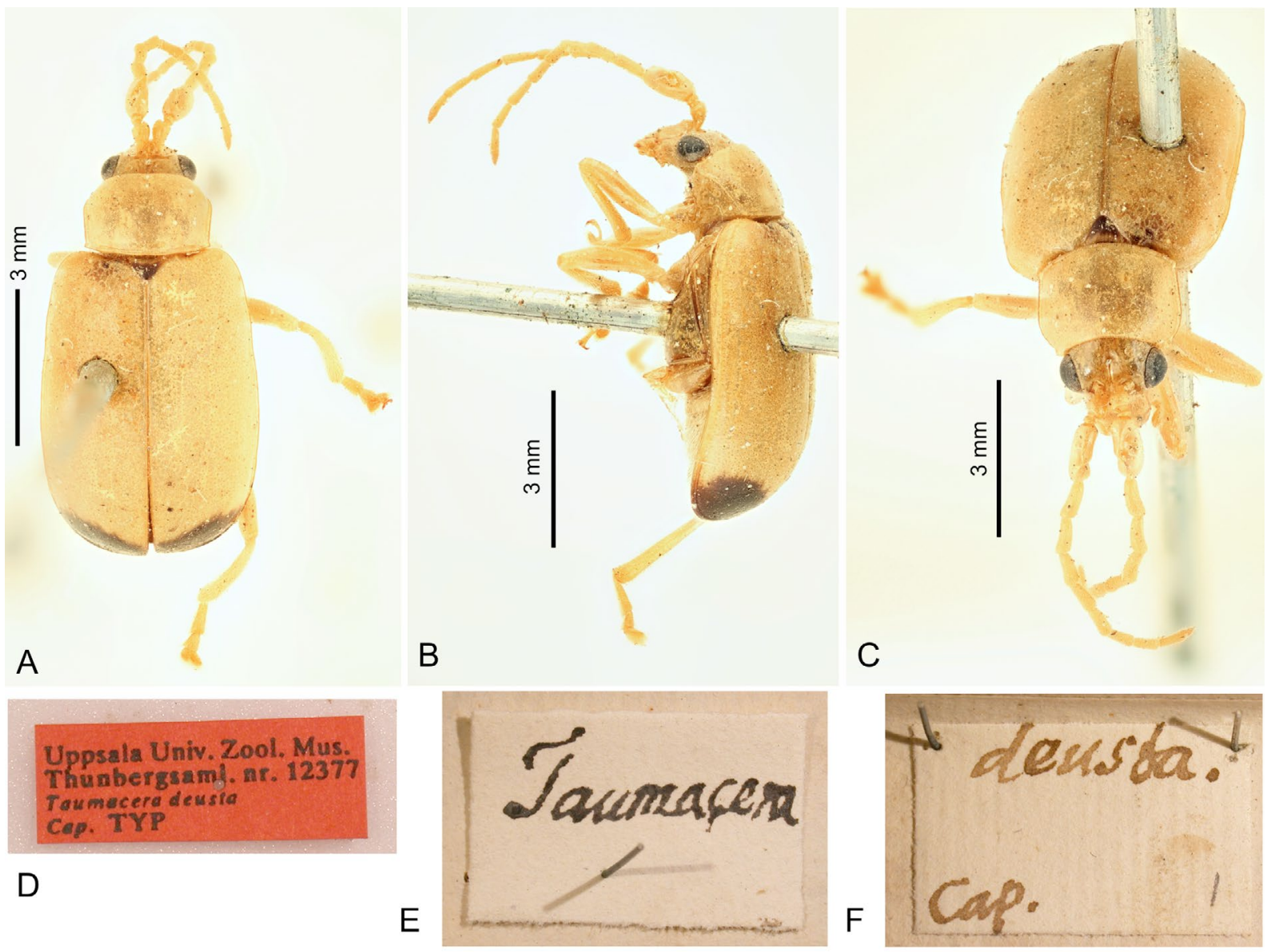

Fig. 18. Taumacera deusta Thunberg, 1814, holotype, $0^{\lambda}, 7.5 \mathrm{~mm}$, UUZM. A. Dorsal view. B. Lateral view. C. Frontal view. D. Label. E. Box label 1. F. Box label 2. 
INDONESIA $• \lambda$, holotype of Nacrea apicipennis; probably Java (see Comments); "Type [white round label with red collar, p] // India or. [w, h] // Nacrea / apicipennis / Baly / India [w, p] // Baly Coll. [w, p]"; BMNH.

\section{Comments}

Thunberg (1814) described Taumacera deusta from "Goda-Hopps Udden" (= Cap. Bon. Spei). Weise (1922) already regarded this type locality as erroneous and correctly synonymized Oedicerus apicipennis Baly, 1879 and Nacrea apicipennis Baly, 1886 (both described from "India") with Taumacera deusta. Based on the paper by Weise (1922), Maulik (1936) and Wilcox (1973) reported India in the distribution of Taumacera deusta. Reid (1999) mentioned that it probably does not occur in India. Based on its currently known distribution, it seems evident that Thunberg collected the holotype during his two visits to Java in the years 1775 and 1777, and later mislabelled it. Taumacera deusta is known also from Bali (Bezděk 2019).

Taumacera deusta is the type species of the species-rich genus Taumacera Thunberg, 1814 (currently ca 70 species, predominantly distributed in the Oriental region). An additional ca 20 African species currently classified in Taumacera are not congeneric and will be transferred elsewhere in the future. The genus concept was recently revised by Bezděk (2019).

\section{Discussion}

Altogether Thunberg described about 100 species of Chrysomelidae, which are generally poorly known. Some species were not found in any subsequent papers and many others, although they can be found in some catalogues, more or less disappeared from the entomological literature. Only a small proportion of the Chrysomelidae type specimens have been recently studied, for example: genus Cassida Linnaeus, 1758 (Sekerka 2008); Chrysomela undata Thunberg, 1784 was stated as a nomen oblitum by Kippenberg (2010); Chrysomela decempustulata Thunberg, 1787 was transferred to Centroscelis Chevrolat, 1836 by Bezděk et al. (2012); Chrysomela superba Thunberg, 1787 to Ambrostoma Motschulsky, 1860 by Ge et al. (2012); or Chrysomela javanica Thunberg, 1787 to Tenebrionidae by Bezděk et al. (2015). A revision of Thunberg's South African Cryptocephalus species is in preparation (Schöller \& Bezděk 2018).

\section{Acknowledgements}

My thanks are due to Hans Mejlon (Museum of Evolution, Uppsala University) for his kind assistance during my stay in Uppsala; to Aisha Mayekiso (IZIKO South African Museum Cape Town) for providing me with the photographs of Peringuey's type specimens; to Elisabeth Grobbelaar (South African National Collection of Insects, Pretoria) for valuable comments on some taxa treated here and, finally, to Michael Geiser and Maxwell V.L. Barclay (Natural History Museum London) for their help during my visit to BMNH. The visits at the Natural History Museum London and Naturhistoriska Riksmuseet Stockholm were supported by the Synthesys Projects SE-TAF-3534 and GB-TAF-6425 (http://www.synthesys.info/) financed by the European Community - Research Infrastructure Action under the Seventh Framework Programme.

\section{References}

Baly J.S. 1879. Descriptions of new genera and species of Gallerucinae. Annals and Magazine of Natural History, series 5 4: 108-120. https://doi.org/10.1080/00222937908679801

Baly J.S. 1886. Descriptions of new genera and species of Galerucidae. Transactions of the Royal Entomological Society of London 1886: 27-39. https://doi.org/10.1111/j.1365-2311.1886.tb02038.x 
BEZDĚK J., Chrysomelidae described by Carl Peter Thunberg

Beenen R. 2010. Galerucinae. In: Löbl I. \& Smetana A. (eds) Catalogue of Palaearctic Coleoptera. Volume 6. Chrysomeloidea: 443-491. Apollo Books, Stenstrup.

Bezděk J. 2016. Identity of taxa proposed in Clythra (Coleoptera: Chrysomelidae: Cryptocephalinae) by Carl Peter Forsberg (1821). Acta Entomologica Musei Nationalis Pragae 56: 769-784.

Bezděk J. 2019. Taumacera revisited, with new synonyms, new combinations and a revised catalogue of the species (Coleoptera: Chrysomelidae: Galerucinae). Acta Entomologica Musei Nationalis Pragae 59 (1): 23-52. https://doi.org/10.2478/aemnp-2019-0003

Bezděk J., Daccordi M. \& Kantner F. 2012. Centroscelis kadleci sp. nov. from Yemen and a new synonymy in the genus Centroscelis (Coleoptera: Chrysomelidae: Chrysomelinae). Acta Entomologica Musei Nationalis Pragae 52: 237-244.

Bezděk J., Purchart L. \& Ando K. 2015. Identity of Chrysomela javanica Thunberg, 1787 (Coleoptera: Chrysomelidae, Tenebrionidae). Annales Zoologici 65: 473-478.

https://doi.org/10.3161/00034541ANZ2015.65.3.003

Bienkowski A.O. 2004. Leaf-Beetles (Coleoptera: Chrysomelidae) of the Eastern Europe. New Key to Subfamilies, Genera, and Species. Mikron-print, Moscow.

Bousquet Y. \& Bouchard P. 2013. The genera in the second catalogue (1833-1836) of Dejean's Coleoptera collection. ZooKeys 282: 1-219. https://doi.org/10.3897/zookeys.282.4401

Bukejs A. 2012. Taxonomical structure and biogeography of leaf-beetles (Coleoptera: Chrysomelidae s. 1.) of the Latvian fauna. Acta Biologica Universitatis Daugavpiliensis 12: 25-34.

Bukejs A. 2013. Catalogue of Latvian leaf-beetles (Coleoptera: Megalopodidae, Orsodacnidae \& Chrysomelidae). Latvijas Entomologs 52: 3-57.

Clavareau H. 1913. Chrysomelidae:5. Megascelinae, 6. Megalopodinae, 7.Clytrinae, 8. Cryptocephalinae, 9. Chlamydinae, 10. Lamprosominae. In: Schenkling S. (ed.) Coleopterorum Catalogus. Pars 53. W. Junk, Berlin.

Chapuis F. 1874. Famille des Phytophages. In: Lacordaire T. \& Chapuis F. Histoire naturelle des insectes. Genera des coléoptères ou exposé méthodique et critique de tous les genres proposés jusqu'ici dans cet ordre d'insectes. Tome dixième. Roret, Paris. https://doi.org/10.5962/bhl.title.8864

DeGeer C. 1778. Mémoires pour servir à l'histoire des Insectes. Tome septième. P. Hesselberg, Stockholm. https://doi.org/10.5962/bhl.title.14802

Dubeshko L.N. \& Medvedev L.N. 1989. Ekologiya listoedov Sibiri i Dalnego Vostoka [Ecology of leafbeetles of Siberia and Far East]. Izdatelstvo Irkutskogo Universiteta, Irkutsk.

Erber D. \& Medvedev L.N. 2002. New and poorly known Clytrinae from Southern Africa, Part 1. Mitteilungen aus dem Museum für Naturkunde in Berlin, Zoologische Reiche 78: 197-206.

https://doi.org/10.1002/mmnz.20020780202

Fabricius J.C. 1781. Species insectorum exhibens eorum differentiasm specificas, synonyma auctorum, loca natalia, metamorphosis, adiectis observationibus. Tome I. Carol Ernest Bohni, Hamburg/Kiel. https://doi.org/10.5962/bhl.title.36509

Fabricius J.C. 1792. Entomologia systematica emendata et aucta. Secundum classes, ordines, genera, species adjectis synonymis, locis, observationibus, descriptionibus. Tom I. Pars II. Christ. Gottl. Proft, Copenhagen. https://doi.org/10.5962/bhl.title.122153

Fabricius J.C. 1798. Supplementum entomologiae systematicae. Proft et Storch, Copenhagen. 
Forsberg C.P. 1821. Monographia Clythrae. Nova Acta Regiae Societatis Scientiarum Upsaliensis 8: 258-292.

Ge S.-Q., Daccordi M., Beutel R.G., Ren J., Cui J.-Z., Li W.-Z. \& Yang X.-K. 2012. Revision of the Eastern Asian genera Ambrostoma Motschulsky and Parambrostoma Chen (Coleoptera: Chrysomelidae: Chrysomelinae). Systematic Entomology 37: 332-345.

https://doi.org/10.1111/j.1365-3113.2012.00618.x

Geiser M. \& Bezděk J. In press. On the identity of Crioceris aulica Fabricius, 1781, a member of Malachiidae misplaced in Chrysomelidae (Coleoptera) and consequent taxonomic changes in Atelechira Lacordaire, 1848. The Coleopterist's Bulletin.

Gemminger M. \& Harold B. 1874. Catalogus Coleopterorum hucusque descriptorum synonymicus et systematicus. Tom. XI. Chrysomelidae (Pars I.). G. Beck, Munich. https://doi.org/10.5962/bhl.title.9089

Goldfuss G.A. 1805. Enumeratio insectorum eleutheratorum Capitis bonae spei totiusque Africae descriptione iconibusque nonnullarum specierum novarum illustrata. Libraria Waltheriana, Erlangen.

Grobbelaar E. 1993. A revision of the southern African species of Megalognatha Baly (Coleoptera: Chrysomelidae). Entomology Memoir of South Africa Department of Agriculture 86: 1-85.

Guskova E.V. 2010. The Leaf-beetles (Coleoptera, Chrysomelidae) of the South Urals. Entomofauna, Zeitschrift für Entomologie 31: 169-228.

ICZN 1999. International Code of Zoological Nomenclature. Fourth Edition. International Trust for Zoological Nomenclature, London. https://doi.org/10.5962/bhl.title.50608

Jacoby M. 1891. On some new species of phytophagous Coleoptera from various regions. The Entomologist 24 (supplement): 35-41.

Jacoby M. 1898. List of the phytophagous Coleoptera obtained by Mr. W. L. Distant in the Transvaal, with descriptions of the new species. Annals and Magazine of Natural History, series 7 1: 344-360. https://doi.org/10.1080/00222939808677985

Jacoby M. 1903. Descriptions of some new species of Clythridae (phytophagous Coleoptera). The Entomologist 36: 91-93.

Jacoby M. \& Clavareau H. 1906. Coleoptera Phytophaga, Fam. Chrysomelidae, Subfam. Clytrinae. In: Wytsman P. (ed) Genera Insectorum. Fasc. 49. V. Verteneuil \& L. Desmet, Brussels.

Jolivet P. \& Verma K.K. 2008. Eumolpinae - a widely distributed and much diversified subfamily of leaf beetles (Coleoptera, Chrysomelidae). Terrestrial Arthropod Reviews 1: 3-37.

https://doi.org/10.1163/187498308X345424

Kippenberg H. 2010. New acts and comments. Chrysomelidae: Chrysomelinae. In: Löbl I. \& Smetana A. (eds) Catalogue of Palaearctic Coleoptera. Volume 6. Chrysomeloidea: 67-73. Apollo Books, Stenstrup.

Klug J.C.F. 1829. Preis-Verzeichniss vorräthiger Insectendoubletten des Königl. zoologischen Museums der Universität. Königl. zoologischen Museums der Universität, Berlin.

Lacordaire J.T. 1848. Monographie des coléoptères subpentamères de la famille des phytophages. Tome second. Mémoires de la Société Royale des Sciences de Liége 5: i-vi + 1-890.

Lawrence J.F. \& Ślipiński A. 2014. Synetinae LeConte and Horn, 1883. In: Leschen R.A.B. \& Beutel R.G. (eds) Handbook of Zoology. Coleoptera, Beetles. Morphology and Systematics. Volume 3: 278284. Walter de Gruyter, Berlin/Boston.

Lee J.-E. 1990. Description of first-instar larva of Syneta adamsi Baly from Japan, with notes on the systematic position of Synetinae (Coleoptera: Chrysomelidae). Esakia 29: 77-81. 
Leiler T.-E. 1973. Fynd av skalbaggar, nya för respektive landskap [New province records of Coleoptera]. Entomologisk Tidskrift 94: 124-125.

Linnaeus C. 1767. Systema Naturae per regna tria naturae, secundum classes, ordines, genera, species, cum characteribus differentiis, synonymis, locis. Editio duodecima, reformata. Tom. I. Pars II. Laurentii Salvii, Holmiae. https://doi.org/10.5962/bhl.title.68927

Mann J.S. \& Crowson R.A. 1981. The systematic positions of Orsodacne Latr. and Syneta Lac. (Coleoptera Chrysomelidae), in relation to characters of larvae, internal anatomy and tarsal vestiture. Journal of Natural History 15: 727-749. https://doi.org/10.1080/00222938100770531

Mann J.S. \& Crowson R.A. 1983. Phylogenetic significances of the ventral nerve cord in the Chrysomeloidea (Coleoptera: Phytophaga). Systematic Entomology 8: 103-119.

https://doi.org/10.1111/j.1365-3113.1983.tb00468.x

Maulik S. 1936. The Fauna of British India including Ceylon and Burma. Coleoptera, Chrysomelidae (Galerucinae). Taylor and Francis, London.

Medvedev L.N. 1970. A contribution to the knowledge of African and Oriental Clytrinae (ColeopteraChrysomelidae). Entomologische Arbeiten aus dem Museum G. Frey 21: 184-195.

Medvedev L.N. 1979. New synonyms in African Clytrinae (Coleoptera: Chrysomelidae). Folia Entomologica Hungarica (series nova) 32: 169-170.

Medvedev L.N. 1982. Listoedy MNR. Opredelitel [Leaf beetles of Mongolia. Identification key]. Nauka, Moscow.

Medvedev L.N. 1989a. A new genus of Clytrinae (Coleoptera, Chrysomelidae) from South Africa. Entomologica Basiliensia 13: 411-415.

Medvedev L.N. 1989b. News on South-African Clytrinae (Coleoptera, Chrysomelidae) with a key to the genus Gyriodera Lac. Polskie Pismo Entomologiczne 58: 775-781.

Medvedev L.N. 1992a. New and poorly known Clytrinae (Coleoptera, Chrysomelidae) from South Africa. Entomologica Basiliensia 15: 389-394.

Medvedev L.N. 1992b. Sem. Chrysomelidae - Listoedy [Fam. Chrysomelidae - Leaf-beetles]. In: Ler P.A. (ed.) Opredelitel' nasekomykh Dal'nego Vostoka SSSR v shestich tomakh. Tom III Zhestkokrylye, ili zhuki. Chast' 2 [Identification Key of Insects of Far East in Six Volumes. Volume III. Beetles, part 2]: 533-602. Nauka, Saint Petersburg.

Medvedev L.N. 1993a. Clytrinae of Southern Africa (Coleoptera, Chrysomelidae). Deutsche Entomologische Zeitschrift 40: 369-389. https://doi.org/10.1002/mmnd.19930400219

Medvedev L.N. 1993b. New data on South African Clytrinae (Coleoptera Chrysomelidae). Russian Entomological Journal 1 (2) (for 1992): 17-24.

Medvedev L.N. 1993c. On several new Clytrinae (Coleoptera, Chrysomelidae) from Namibia and Angola. Russian Entomological Journal 2 (2): 3-7.

Medvedev L.N. 1993d. New species and a new genus of South African Clytrinae (Coleoptera: Chrysomelidae). Annals of the Transvaal Museum 36: 1-8.

Medvedev L.N. 2008. African Clytrinae (Coleoptera, Chrysomelidae) in the collection of the Institut Royal des Sciences Naturelle de Belgique. Bulletin de l'Institut Royal des Sciences Naturelles de Belgique, Entomologie 78: 145-153.

Medvedev L.N. 2012. New and interesting Chrysomelidae (Insecta: Coleoptera) from the collection of the Naturkundemuseum Erfurt. Vernate 31: 489-503. 
Medvedev L.N. \& Dubeshko L.N. 1992. Opredelitel listoedov Sibiri [Identification Key of Leaf-Beetles of Siberia]. Izdatelstvo Irkutskogo Universiteta, Irkutsk.

Medvedev L.N. \& Erber D. 2003. New species of Afrotropical Clytrinae (Coleoptera: Chrysomelidae), with new data on several known species. Annals of the Transvaal Museum 40: 73-90.

Medvedev L.N. \& Regalin R. 1997. Plecophthalma n. gen. di Clytrinae Afrotropicali (Coleoptera, Chrysomelidae). Bollettino del Museo Civico di Storia Naturale di Venezia 47 (for 1996): 135-151.

Medvedev L. N. \& Zaitsev Yu.M. 1978. Lichinki zhukov-listoedov Sibiri i Dalnego Vostoka [Larvae of Leaf-Beetles of Siberia and Far East]. Nauka, Moscow.

Monrós F. 1953. Some corrections in the nomenclature of Clytrinae (Chrysomelidae). Coleopterists Bulletin 7: 45-50.

Muller S. \& Roomaaker L. C. 1992. The South African insects described by Carl Peter Thunberg (17431828). Journal of Namibia Scientific Society 43: 81-105.

Nie R.-E., Bezděk J. \& Yang X.-K. 2017. How many genera and species of Galerucinae s. str. do we know? Updated statistics (Coleoptera, Chrysomelidae). ZooKeys 720: 91-102 + supplementary file. https://doi.org/10.3897/zookeys.720.13517

Olivier A.G. 1808. Entomologie, ou histoire naturelle des insectes, avec leurs caractères génériques et spécifiques, leur description, leur synonymie et leur figure enluminée. Coléoptères. Tome sixième. Baudonin, Paris. https://doi.org/10.5962/bhl.title.61905

Papp C.S. 1951. Deux nouveaux chrysomélides (Col.) nord-africains (Contribution à l'étude des chrysomélides, $\mathrm{n}^{\circ}$ 36). Bulletin de la Société des Sciences Naturelles du Maroc 30 (for 1950): 81-84.

Regalin R. \& Medvedev L.N. 2010. Cryptocephalinae: Clytrini. In: Löbl I. \& Smetana A. (eds) Catalogue of Palaearctic Coleoptera. Volume 6. Chrysomeloidea: 564-580. Apollo Books, Stenstrup.

Reid C.A.M. 1999. Reappraisal of the genus Taumacera Thunberg with descriptions of two new species from South-East Asia (Coleoptera: Chrysomelidae: Galerucinae). Australian Journal of Entomology 38: $1-9$.

Samuelson G.A. 1994. Pollen consumption and digestion by leaf beetles. In: Jolivet P.H., Cox M.L. \& Petitpierre E. (eds) Novel Aspects of the Biology of Chrysomelidae: 179-183. Kluwer Academic Publishers, Dordrecht.

Schawaller W. 1990. Käfer aus Sibirien (Umgebung Novosibirsk) (Insecta: Coleoptera). Beiträge zur Entomologie 40: 231-245.

Schöller M. \& Bezděk J. 2018. Cryptocephalus species described from South Africa by Johan Christian Fabricius and Carl Peter Thunberg (Coleoptera: Cryptocephalinae: Cryptocephalini). Annales Zoologici 68 (4): 749-768. https://doi.org/10.3161/00034541ANZ2018.68.4.003

Schoenherr C.J. 1808. Synonymia Insectorum, oder: Versuch einer Synonymie aller bisher bekannten Insecten; nach Fabricii Systema Eleutheratorum \&c. geordnet. Erster Band. Eleutherata oder Käfer. Zweiter Theil. Spercheus---Cryptocephalus. C. F. Marquard, Stockholm. https://doi.org/10.5962/bhl.title.66107

Scopoli J.A. 1763. Entomologia Carniolica exhibens insecta Carnioliae indigena et distributa in ordines, genera, species, varietates. Methodo linnaeana. Ioannis Thomae Trattner, Wien.

https://doi.org/10.5962/bhl.title.34434

Sekerka L. 2008. Species of Cassida Linné, 1758 described by Thunberg and their present status (Coleoptera: Chrysomelidae: Cassidinae). Genus 19: 301-306. 
Silfverberg H. 2004. Enumeratio nova Coleopterorum Fennoscandiae, Daniae et Baltiae. Sahlbergia 9: $1-111$.

Silfverberg H. 2010a. Enumeratio renovata Coleopterorum Fennoscandiae, Daniae et Baltiae. Sahlbergia $16(2): 1-144$.

Silfverberg H. 2010b. Synetinae. In: Löbl I. \& Smetana A. (eds) Catalogue of Palaearctic Coleoptera. Volume 6. Chrysomeloidea: 643. Apollo Books, Stenstrup.

Telnov D. 2004. Compendium of Latvian Coleoptera. Volume I. Check-list of Latvian beetles (Insecta: Coleoptera). Second edition. Entomological Society of Latvia, Riga.

Telnov D. \& Kalniņš M. 2003. To the knowledge of Latvian Coleoptera. 3. Latvijas Entomologs 40: 21-33.

Thunberg C.P. 1787. D. D. Museum Naturalium Academiae Upsaliensis. Partem quartam. Joh. Edman, Uppsala.

Thunberg C.P. 1814. Beskrifning på tvänne nya insect-slägten, Gnatocerus och Taumacera från GodaHopps Udden. Kongl. Vetenskaps Academiens Handlingar (Stockholm) 1814: 46-50.

Thunberg C.P. 1821. Coleoptera Capensia, antennis fusiformibus. Nova Acta Regiae Societatis Scientiarum Upsaliensis 8: 157-193.

Thunberg C.P. 1827. Coleoptera Capensia, antennis filiformibus, enumerata et nova decsripta. Nova Acta Regiae Societatis Scientiarum Upsaliensis 9: 1-52.

Wagner T. 2005. Revision of the vincta species-group of Monolepta Chevrolat, 1837 from Africa, Arabia and the Near East (Coleoptera: Chrysomelidae, Galerucinae). Bonner Zoologische Beiträge 53 (for 2004): 255-282.

Wagner T. 2007. Monolepta Chevrolat, 1837, the most speciose galerucine taxon: redescription of the type species Monolepta bioculata (Fabricius, 1781) and key to related genera from (Chrysomelidae, Coleoptera). Journal of Natural History 41: 81-100. https://doi.org/10.1080/00222930601127384

Wallin L. \& Wallin H. 2001. Catalogue of Type Specimens. 1. C. P. Thunberg (1743-1828), Insecta. Revised version 6. Uppsala University, Museum of Evolution, Zoology section (UUMZ). Available from: http://www.evolutionsmuseet.uu.se/samling/UUZM01_Thunberg.pdf [accessed 30 May 2018].

Warchałowski A. 2003. Chrysomelidae. The Leaf-Beetles of Europe and the Mediterranean Area. Natura Optima Dux Foundation, Warsaw.

Warchałowski A. 2010. The Palaearctic Chrysomelidae. Identification keys. Volume 1. Natura Optima Dux Foundation, Warsaw.

Weise J. 1922. Chrysomeliden der Indo-Malayischen Region. Tijdschrift voor Entomologie 65: 39-130.

Wiedemann C.R.W. 1823. Zweihundert neue Käfer von Java, Bengalen und dem Vorgebirge der Guten Hoffnung. Zoologisches Magazin 2 (1): 1-135.

Wilcox J.A. 1973. Chrysomelidae: Galerucinae (Luperini: Luperina). In: Wilcox J.A. (ed) Coleopterorum Catalogus Supplementa. Pars 78(3). Second edition. W. Junk, 's-Gravenhage.

Manuscript received: 31 August 2018

Manuscript accepted: 12 November 2018

Published on: 19 February 2019

Topic editor: Gavin Broad 
Section editor: Max Barclay

Desk editor: Pepe Fernández

Printed versions of all papers are also deposited in the libraries of the institutes that are members of the EJT consortium: Muséum national d'Histoire naturelle, Paris, France; Meise Botanic Garden, Belgium; Royal Museum for Central Africa, Tervuren, Belgium; Royal Belgian Institute of Natural Sciences, Brussels, Belgium; Natural History Museum of Denmark, Copenhagen, Denmark; Naturalis Biodiversity Center, Leiden, the Netherlands; Museo Nacional de Ciencias Naturales-CSIC, Madrid, Spain; Real Jardín Botánico de Madrid CSIC, Spain; Zoological Research Museum Alexander Koenig, Bonn, Germany. 